Article

\title{
Application of Fuzzy Analytic Hierarchy Process to Underground Mining Method Selection
}

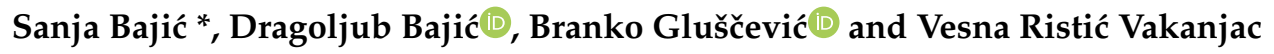 \\ Faculty of Mining and Geology, University of Belgrade, 11000 Belgrade, Serbia; \\ dragoljub.bajic@rgf.bg.ac.rs (D.B.); branko.gluscevic@rgf.bg.ac.rs (B.G.); vesna.ristic@rgf.bg.ac.rs (V.R.V.) \\ * Correspondence: sanja.bajic@rgf.bg.ac.rs
}

Received: 30 December 2019; Accepted: 14 January 2020; Published: 23 January 2020

\begin{abstract}
The paper proposes a problem-solving approach in the area of underground mining, related to the evaluation and selection of the optimal mining method, employing fuzzy multiple-criteria optimization. The application of fuzzy logic to decision-making in multiple-criteria optimization is particularly useful in cases where not enough information is available about a given system, and where expert knowledge and experience are an important aspect. With a straightforward objective, multiple-criteria decision-making is used to rank various mining methods relative to a set of criteria and to select the optimal solution. The considered mining methods represent possible alternatives. In addition, various criteria and subcriteria that influence the selection of the best available solution are defined and analyzed. The final decision concerning the selection of the optimal mining method is made based on mathematical optimization calculations. The paper demonstrates the proposed approach as applied in a case study.
\end{abstract}

Keywords: multiple-criteria decision-making; underground mines; mining methods; expert knowledge

\section{Introduction}

It is well-known that in most cases, a large number of criteria and subcriteria for decision-making matrices are uncertain and decision makers are unable to arrive at exact numerical values for comparing decisions. As such, mathematical methods are needed to effectively treat uncertainty, vagueness, and subjectivity. Viewed from that perspective, fuzzy logic is a scientifically based approach that relies on experience and intuition (or expert judgment). The fuzzy analytic hierarchy process (FAHP) enables the evaluation and analysis of criteria using fuzzified evaluation scales based on Saaty's scale [1].

In recent years, scientists worldwide have introduced a number of new theories and procedures for selecting underground mining methods, which generally involve gray correlation and multiple-criteria decision-making (AHP, FAHP, TOPSIS, PROMETHEE, ELECTRE, and VIKOR). Multiple-criteria decision-making (MCDM) methods have been demonstrated as useful problem-solving tools in various fields of engineering [2-4]. FAHP is widely applied. Guo et al. [5] used FAHP to determine evaluation index weights when they assessed the stability of a worksite above an abandoned coalmine, which threatened the safety of a high-speed railroad line. Pipatprapa et al. [6] used structural equation modeling (SEM) and FAHP to investigate factors suitable for assessing the environmental performance of the food industry. Lee et al. [7] proposed an FAHP-based decision-making model for selecting the best location for a frontal solar facility, given that the electric power demand, fossil fuel depletion, and environmental awareness necessitate power supply from renewable sources. Chatterjee \& Stević [8] used FAHP for supplier selection in supply chain management. Božanić et al. [9] compare the FAHP method to another method that uses the fuzzy approach in MCDM for ranking the locations for deep wading as a technique of crossing the river by the army tank units. Stanković et al. [10] used FAHP 
for determining the importance of the traffic accessibility criteria. Mallick et al. [11] applied FAHP in groundwater management of a semi-arid region.

An in-depth literature review revealed that much research has used MCDM techniques to define optimal mining methods for different ores. Özfırat [12] applied FAHP to assess the use of certain machinery in the Amasra coalmine, in order to boost production, downsize the workforce and, consequently, reduce the number of accidents. Chander et al. [13] propose a decision-making technique for the selection of the optimal underground bauxite mining method. Based on AHP and VIKOR multiple-criteria optimization techniques, their results show that the optimal mining method, in that case, was cut-and-fill. Balusa \& Gorai [14] compare mining methods using five MCDM models (TOPSIS, VIKOR, ELECTRE, PROMETHEE II, and WPM). They employed AHP to determine the weights of effective criteria for the Tummalapalle uranium mine in India. The results indicate that the selected mining methods were not equally efficient. Balusa \& Gorai [15] used FAHP to select suitable underground mining methods. Bogdanovic et al. [16] employed a combination of AHP and PROMETHEE to select the most suitable mining method for the Čoka Marin underground mine in Serbia: AHP to analyze the structure of the problem and determine criteria weights, and PROMETHEE for final ranking and sensitivity analysis. Alpay \& Yavuz [17] developed a decision-making support system for the Karaburun underground chromite mine in Eskisehir, Turkey. They applied AHP to find acceptable alternatives. Yazdani-Chamzini et al. [18] proposed a selection model for the optimal mining method at the Angouran mine, one of the main producers of zinc in Iran. They developed the model based on FAHP and FTOPSIS. Then Asadi et al. [19] used a TOPSIS model to select the optimal mining method for the Tazareh coalmine in Iran. Javanshirgiv \& Safari [20] applied fuzzy TOPSIS to select the optimal mining method for the Kamar Mahdi mine in Iran. Ataei et al. [21] also used TOPSIS to do the same for the Jajarm mine in Iran. For this mine, Naghadehi et al. [22] proposed a combination of FAHP and AHP: FAHP to determine criteria weights and AHP to rank the mining methods. On the other hand, some researchers have employed MCDM models to address mine dewatering, which is a parallel process in mining operations. Bajić et al. [23] describe the selection of the optimal groundwater control system for the open cast-mine Buvač (Bosnia and Herzegovina), using soft optimization and fuzzy optimization (VIKOR and FAHP) techniques. For the same case study, Polomčić et al. [24] performed mathematical optimization calculations applying fuzzy dynamic TOPSIS.

The present paper describes and tests a decision-making algorithm for the selection of the optimal underground mining method. The algorithm is applied in a real case study to the Borska Reka copper mine (Serbia). First, the relevant alternatives are identified and then the selection criteria are analyzed. This if followed by MCDM, to select the optimal mining method. Finally, the best choice is the method that maximizes the output of useful components and minimizes tailings. In addition, the optimal solution involves the shortest mining time and the lowest consumption of energy and materials, along with full safety at work and no adverse effect on mine development.

\section{Case Study}

The FAHP-based methodology for decision-making on the optimal underground mining method was applied in a real case study. The study area is the Borska Reka copper mine in eastern Serbia (Figure 1). In terms of regional metallogeny, the Bor ore field and Borska Reka copper mine belong the so-called Bor Zone, which coincides with the Timok igneous complex. In geologic terms, the sediments are composed of volcanites and volcanoclastic rocks, quartz-diorite porphyritic rocks, hydrothermally altered volcanic and volcanoclastic rocks, pelites with tuffs and tuffites, conglomerates, sandstones, Quaternary alluvial sediments, and technogenic deposits.

The mineral composition of the ore from Borska Reka includes chalcopyrite, covellite, chalcosine, rutile, hematite, magnetite, sphalerite, galenite, tetrahedrite, tennantite, digenite, cubanite, and native gold. The prevalent ore is pyrite, the dominant copper mineral is chalcopyrite, and there are covellite, chalcosine, and bornite to a lesser extent. On the other hand, enargite and molybdenite are very rare. However, this ratio of copper minerals is not uniform across the ore body. Certain parts have 
elevated concentrations of covellite, chalcosine and bornite, but they are rarely dominant. There are also frequent occurrences of rutile, magnetite and hematite, as well as sphalerite and galenite. Tetrahedrite tennantite, digenite, cubanite and native gold are very rare and occur sporadically.

Past exploration has revealed that the Borska Reka ore body is among very large deposits in the geometric sense, with elevated copper concentrations. The ore body is at an angle of $45^{\circ}-55^{\circ}$. Its maximum length is $\sim 1.410 \mathrm{~m}$ and maximum width $635 \mathrm{~m}$. The ore body is deep; the average ultimate depth is $\sim 920 \mathrm{~m}$ from the ground surface.

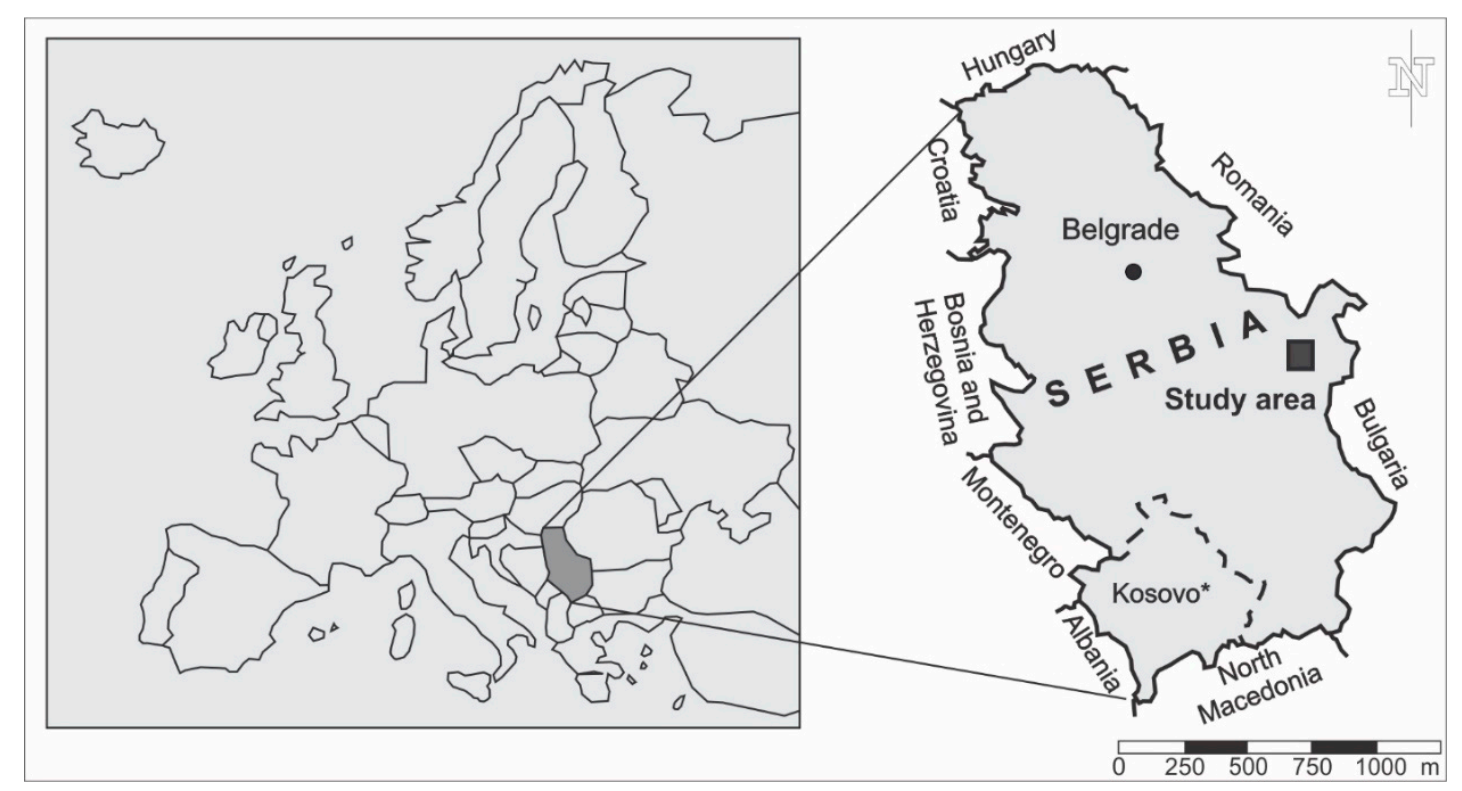

Figure 1. Geographic position of the study area: Borska Reka copper mine.

\section{Methodology}

The underground mining decision-making algorithm is shown in Figure 2. FAHP is the optimization technique. In general, one of the limiting factors of conventional methods applied to select the optimal mining technology is often a lack of data. Mines are complex geologic systems and mining operations are dynamic as the size and depth of the mine constantly increase (in plain view and elevation). As such, mining requires continual adaptation to new conditions. The contribution to science of decision-making methods based on fuzzy logic is the ability to focus on overcoming uncertainties inherent in mining method selection.

On the other hand, compared to other methods that include the fuzzy approach, FAHP offers certain specific advantages in optimal underground mining method selection. Because of the depth of the ore deposit and imprecise data typical of such a geologic system, which make it impossible to accurately define all the physical, mechanical and geologic conditions, the entire mining process requires constant "learning" and gradual, hierarchical problem-solving, to achieve the set objective. FAHP involves a continual "learning process", along with discussion among experts and prioritizing.

Consequently, the use of FAHP highlighted the quality of this technique based on expert judgment or, in other words, reflected the decision-makers' knowledge and experience in evaluating information, to arrive at an optimal decision concerning multiple alternative underground mining methods. 


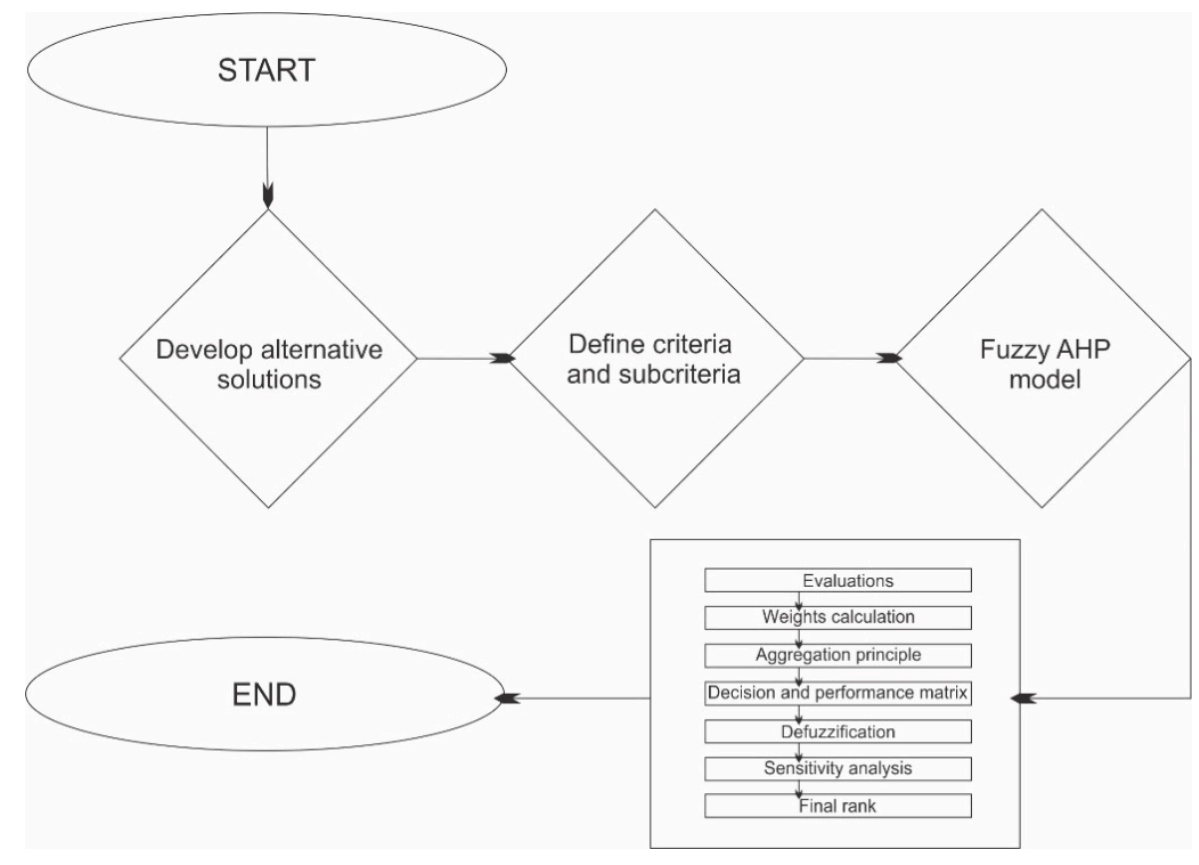

Figure 2. Multiple-criteria decision-making (MCDM) model for the selection of optimal underground mining method.

FAHP is a combination of the conventional AHP method [1] and the fuzzy set theory [25]. It is implemented using triangular fuzzy numbers [26]. TFN (Figure 3) in set $R$ is a triangular fuzzy number if its membership function $\mu_{M}(x): R \rightarrow[0,1]$ is defined as follows:

$$
\mu_{T F N}(x)= \begin{cases}\frac{x}{s-l}-\frac{l}{s-l}, & x \in[l, s] \\ \frac{x}{s-d}-\frac{d}{s-d}, & x \in[s, d] \\ 0, & x \notin[l, d]\end{cases}
$$

where $l \leq s \leq d$.

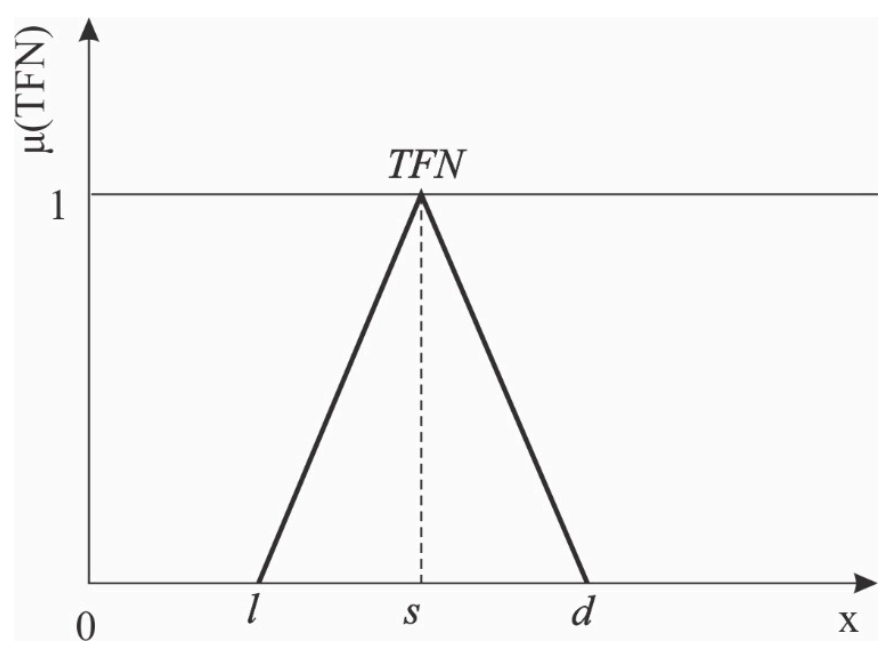

Figure 3. Membership function of triangular fuzzy number (TFN).

The modification of AHP into FAHP is in that the relative importance of the optimality criteria is described by linguistic variables [27], determined by the expert, and modeled by triangular fuzzy numbers (TFN). In other words, fuzzy numbers describe the pairwise comparison matrices of the 
optimality criteria. The fuzzified Saaty scale, proposed by many authors $[26,28-30]$ is used. One of them is shown in Table 1.

Table 1. Fuzzified scale [26,30].

\begin{tabular}{ccc}
\hline Linguistic Variable & FAHP Scale \\
(Definition of Importance) & AHP Scale & TFN \\
\cline { 3 - 3 } & & $(0.5 \leq \boldsymbol{\alpha} \leq 2)$ \\
\hline Equal & 1 & $(1,1,1+\alpha)$ \\
Weak & 3 & $(3-\alpha, 3,3+\alpha)$ \\
Strong & 5 & $(5-\alpha, 5,5+\alpha)$ \\
Proven dominance & 7 & $(7-\alpha, 7,7+\alpha)$ \\
Absolute dominance & 9 & $(9-\alpha, 9,9)$ \\
Intermediate values & $2,4,6,8$ & $(x-1, x, x+1)$ \\
& & $x=2,4,6,8$ \\
\hline
\end{tabular}

Chang [26] made the first development steps and Deng [30] modified the method. Also, Bajić et al. [23] applied fuzzy optimization to mine hydrogeology. Based on the above, the FAHP analysis was implemented in the following steps:

(a) First the problem relating to the selection of the underground mining method was examined and the alternatives and criteria/subcriteria that influence the selection of the optimal alternative were identified. This involved the selection of a team of experts and the "exploitation" of their knowledge and experience.

(b) Pairs of criteria (Equation (1)), subcriteria (Equation (2)) and alternatives (Equation (3)) were evaluated and compared using the FAHP scale (Table 1):

$$
A=\left[\begin{array}{cccc}
a_{11} & a_{12} & \cdots & a_{1 m} \\
a_{21} & a_{22} & \cdots & a_{2 m} \\
\cdots & \cdots & \cdots & \cdots \\
a_{m 1} & a_{m 2} & \cdots & a_{m m}
\end{array}\right]
$$

where: $a_{i j}=1$ for every $i=j,(i, j=1,2, \ldots, m)$ and $a_{i j}=\frac{1}{a_{j i}}$

$$
A_{j}=\left[\begin{array}{cccc}
a_{11} & a_{12} & \cdots & a_{1 k_{j}} \\
a_{21} & a_{22} & \cdots & a_{2 k_{j}} \\
\cdots & \cdots & \cdots & \cdots \\
a_{k_{j} 1} & a_{k_{j} 2} & \cdots & a_{k_{j} k_{j}}
\end{array}\right]
$$

where criterion $C_{j}$ is composed of $k_{j}$ subcriteria,

$$
Y_{k}=\left[\begin{array}{cccc}
a_{11} & a_{12} & \cdots & a_{1 N} \\
a_{21} & a_{22} & \cdots & a_{2 N} \\
\cdots & \cdots & \cdots & \cdots \\
a_{N 1} & a_{N 2} & \cdots & a_{N N}
\end{array}\right]
$$

where $N$ is the number of alternatives relative to each of the $K$ subcriteria; $k=1,2, \ldots, K$.

(c) The weights of all three matrices from step $\mathbf{b}$ are determined gradually, using fuzzy extent analysis [26] or fuzzy arithmetic and the extension principle [31]. All the resulting weights are normalized:

$$
w_{i}=\sum_{j=1}^{m} a_{i j} \otimes\left[\sum_{k=1}^{m} \sum_{l=1}^{m} a_{k l}\right]^{-1}
$$


where $i=1,2, \ldots, m$

$$
w_{j}^{\prime}=\left(\sum_{l=1}^{k_{j}} a_{i l} \otimes\left[\sum_{i=1}^{k_{j}} \sum_{l=1}^{k_{j}} a_{i l}\right]^{-1}\right) \otimes w_{j}
$$

where $j=1,2, \ldots, m ; p=1,2, \ldots, k_{j}$

$$
W=\left(w_{1}^{1}, w_{1}^{2}, \ldots, w_{1}^{k_{1}} ; w_{2}^{1}, w_{2}^{2} \ldots w_{2}^{k_{2}} ; \ldots ; w_{j}^{1}, w_{j}^{2}, \ldots, w_{j}^{k_{j}} ; \ldots ; w_{m}^{1}, w_{m}^{2}, \ldots, w_{m}^{k_{m}}\right)
$$

where $W$ are subcriteria weights, whose total "length" is $K$

$$
W=\left(W_{1}, W_{2}, \ldots, W_{K}\right)
$$

(d) The next step is the application of the aggregation principle, to reduce two hierarchy tiers (criteria and subcriteria) to a single tier:

$$
K=\sum_{j=1}^{m} k_{j}
$$

where $C_{1}, C_{2}, \ldots, C_{m}$ is a set of $m$ criteria, each with its subcriteria; $k_{j}$-number of subcriteria of the $j$-th criterion.

(e) The fuzzy decision matrix and fuzzy performance matrix are now calculated. The fuzzy decision matrix results from calculations of the fuzzy extent analysis from step $c$ for the alternatives:

$$
X=\left[\begin{array}{cccc}
x_{11} & x_{12} & \cdots & x_{1 K} \\
x_{21} & x_{22} & \cdots & x_{2 K} \\
\cdots & \cdots & \cdots & \cdots \\
x_{N 1} & x_{N 2} & \cdots & x_{N K}
\end{array}\right]
$$

and the fuzzy performance matrix represents the overall performance of each alternative relative to all the subcriteria:

$$
Z=\left[\begin{array}{cccc}
x_{11} \otimes W_{1} & x_{12} \otimes W_{2} & \cdots & x_{1 K} \otimes W_{K} \\
x_{21} \otimes W_{1} & x_{22} \otimes W_{2} & \cdots & x_{2 K} \otimes W_{K} \\
\cdots & \cdots & \cdots & \cdots \\
x_{N 1} \otimes W_{1} & x_{N 2} \otimes W_{2} & \cdots & x_{N K} \otimes W_{K}
\end{array}\right]
$$

(f) The ultimate values of the alternatives are calculated in the form of triangular fuzzy numbers:

$$
F_{i}=\sum_{j=1}^{K} x_{i j} \otimes W_{j}
$$

(g) The final step includes defuzzification [32], ranking of alternatives and, in parallel, sensitivity analysis $[33,34]$. The optimal alternative is the one with the greatest weight. The sum of the weights of all the alternatives is equal to zero:

$$
\operatorname{defuzzy}(A)=\frac{(d-l)+(s-l)}{3}+l
$$

The sensitivity analysis is performed by introducing the optimization index $\lambda$. The "total integral" $-I$ is calculated, to express the expert's risk assessment $(0-$ pessimistic, 1 -optimistic, and 0.5 -moderate):

$$
I=\frac{(d \lambda+s+(1-\lambda) l)}{2}, \quad \lambda \in[0,1]
$$

where: $l, s$ and $d$ are elements of the triangular fuzzy number. 
A special-purpose application, Fuzzy-GWCS2 based on Microsoft Excel, was developed for the above mathematical optimization calculations. The objective was to provide clearer insight into the results and facilitate monitoring of changes in the final calculations during the sensitivity analysis.

\section{Results and Discussion}

FAHP-aided selection of underground mining methods enables efficient decision-making and facilitates solving of complex problems that involve vagueness and multiple uncertainties, like in the case of the Borska Reka copper mine. The first uncertainty was associated with the identification of all lithostratigraphic units. This copper deposit is highly specific, with occurrences of numerous minerals. On the other hand, there was a lack of information on its geometry and certain physical indicators and parameters pertaining to the ore and surrounding rocks.

Calculations were made using the MCDM model (or the algorithm shown in Figure 2), to determine the best mining alternative for the Borska Reka copper mine. The procedure was gradual, following the above steps $a-g$ and using the specially developed Fuzzy-GWCS2 application.

The selection of a team of experts and "exploitation" of their knowledge and experience play a key role in decision- making and underground mining method selection. Teamwork ensures technically sustainable, economically viable and, above all, safe mining of copper ore.

Successful underground mining method selection requires substantial knowledge about the geology of the mineral ore deposit. In addition, the depth of the mine necessitates exploratory drilling experience. Because of the specific features of copper deposits, petrologists, mineralogists and geochemists contribute key knowledge and analysis of the minerals and their physical parameters. Hydrogeologists examine groundwater flow to the mine and ways of protecting the mine. Experts in economic geology and mine management assess the technoeconomic viability of mining. Geologists define the characteristics of the ore deposit. As a result, mining experts gain insight into applicable underground mining methods and develop alternative solutions. Engineers then synthesize the information and define and asses the criteria than affect the selection of the preferred underground mining method. The quality of the identification of mining conditions and the experts' knowledge and experience directly influence the selection of the optimal method.

The given problem - selection of the optimal underground mining method-was examined in step $\boldsymbol{a}$. Then the criteria and subcriteria that influence the selection were defined. Based on literature sources that address the selection of underground mining methods and the governing factors [18,35], the following three criteria were identified: technical, production, and economic.

The criteria were subdivided into subcriteria, in this case 18, as shown in Table 2. Given the different types of essentially opposed criteria, the MCDM approach was a reasonable and justifiable choice.

In addition, five different alternatives (underground mining methods) were defined, including:

Alternative 1-sublevel caving;

Alternative 2-cut and fill;

Alternative 3-shrinkage stoping;

Alternative 4-block caving;

Alternative 5-vertical crater retreat (VCR)

Mining methods depend on the shape, size and depth of the ore body, physical and mechanical properties of the ore and accompanying rocks, hydrologic conditions, sensitivity of ground surface to mining, mineral and chemical composition of the ore, mineral distribution, and value of ore. Consequently, all these characteristics are important and need to be taken into account when a decision is made about the optimal mining method.

In the case of ore bodies of irregular shape, such as that at Borska Reka, priority is usually given to a caving method. The ore body size is often the decisive factor, because it reflects ore reserves. In addition, the thickness of the ore body is important, as are its depth, angle, type of contact and tectonic circumstances. At large depths, the cut-and-fill method should be given priority over block caving. 
Table 2. Defining of criteria and subcriteria.

\begin{tabular}{cccc}
\hline Criterion & Symbol & Subcriteria & Symbol \\
\hline & & Depth of ore body & $\mathrm{T}_{1}$ \\
& & Thickness of ore body & $\mathrm{T}_{2}$ \\
Technical & $\mathrm{T}$ & Shape of ore body & $\mathrm{T}_{3}$ \\
& & Value of ore & $\mathrm{T}_{4}$ \\
& & Ore body slope (angle) & $\mathrm{T}_{5}$ \\
& & Rock hardness and stability & $\mathrm{T}_{6}$ \\
& & Mineral and chemical composition of ore & $\mathrm{T}_{7}$ \\
& & Mining method productivity and output & $\mathrm{T}_{8}$ \\
\hline \multirow{3}{*}{ Production } & Safety at work & $\mathrm{P}_{1}$ \\
& $\mathrm{P}$ & Adverse environmental impact & $\mathrm{P}_{2}$ \\
& & Ore dilution & $\mathrm{P}_{3}$ \\
& & Ore impoverishment & $\mathrm{P}_{4}$ \\
& & Ventilation & $\mathrm{P}_{5}$ \\
& & Hydrologic conditions & $\mathrm{P}_{6}$ \\
& & Capital expenditure & $\mathrm{P}_{7}$ \\
\hline
\end{tabular}

In the present case study, the mineral and chemical composition was important because of the presence of pyrite and pyrrhotite. Copper pyrite ore, with more than $40 \%$ of sulfur, as well as other sulfide ores with elevated concentrations of pyrite and pyrrhotite, are susceptible to oxidation, self-ignition and sticking. If the ore is left in a crushed state for a long time, it becomes oxidized and warm in contact with air and humidity. This reduces the ore utilization rate. As such, if the ore contains large amounts of pyrite and pyrrhotite, cut-and-fill methods are given priority over shrinkage stoping or block caving methods. If the ore is highly valuable, often the method of choice is less effective but with a much higher ore utilization rate than vice-versa.

Ore impoverishment is the reduction in metal content of the produced ore, relative to that of the excavated block. Shrinkage stoping and caving methods typically lead to greater impoverishment. Also, even cut-and-fill methods, where the ore is loaded by means of mechanical devices (scrapers or shovels) directly from the fill, tend to result in a higher level of impoverishment. In general, however, cut-and-fill and block caving, compared to other methods, cause less impoverishment. In the case of the room-and-pillar methods, secondary cutting invariably leads to impoverishment because the ore is mixed with side or roof gangue.

Physical and mechanical characteristics are also taken into account. Rock hardness and stability tend to be the most important parameters because they affect the span and surface of the tunnels. With regard to hydrologic circumstances, the amount and properties of groundwater need to be known, particularly its effect on "plastic" rocks such as clays. The presence of water-bearing rocks and stagnant groundwater hinder the shrinkage stoping method. The preferred technologies are cut-and- fill (with hydraulic or paste backfill) or room-and-pillar mining methods. If the ore mineral distribution is not uniform, cut-and-fill methods are given priority.

Safety at work is an extremely important factor. The economic advantages of a given mining method should not threaten people's lives, operations or the safety of mine installations. The selected mining method should not be capable of causing fire, inrush of groundwater or surface water, caving of underground or above-ground mine walls or other structural components, or endanger miners and mining. A healthy work environment requires good ventilation (fresh air supply and venting of harmful gases and dust), proper illumination and safe access to work stations, as well as machinery to relieve miners of heavy manual work and measures to ensure health protection. Certain underground mining methods degrade the environment by damaging the soil and potentially causing land subsidence. On the other hand, the productivity of the mining method is important in the technoeconomic 
assessment of a mine, given that a higher productivity leads to greater output. The productivity of a method is based on the rate of mining of blocks or parts of the ore body, and the capacity of the ore body depends on the ability to mine all active levels. The costs of mining are also examined, because spending is required before there can be a return on investment (such as for shafts or declines, mining equipment, crushers, transporters, and venting and dewatering systems). Also, there are costs associated with excavation (e.g., materials for tunneling and consumables such as ANFO explosives, detonators, drilling tools, diesel fuel, oil, lubricants, loader and transporter tires, steel, steel cables and cement, as well as the preparation and distribution of backfill paste, along with associated labor) and maintenance costs (of machinery and installations, as well as depreciation, overhead, etc.).

In view of the above facts and given that Borska Reka belongs to the group of ore bodies with relatively high copper concentrations, that the ore body is deep and that there are structures and facilities on the land surface, the research warranted the consideration of five high-productivity mining methods, which would ensure economically viable mining.

The criteria, subcriteria and alternatives were evaluated and the scores were input parameters for the MCDA model. Their weights determined in the form of fuzzy numbers per steps $b$ and $c$. Equation (1) was used to evaluate the criteria, Equation (2) the subcriteria, and Equation (3) the alternatives. Evaluation was based on pairwise comparison (of criteria, subcriteria and alternatives), using linguistic variables and their numerical values from FAHP scales (Table 1). Table 3 shows the criteria scores in the form of triangular fuzzy numbers and their relative importance. Equations (4) through (7) were used to calculate weights by fuzzy extent analysis.

Table 3. Evaluation of criteria.

\begin{tabular}{cccccccccc}
\hline & \multicolumn{3}{c}{ T } & \multicolumn{3}{c}{ P } & \multicolumn{3}{c}{ E } \\
\cline { 2 - 10 } & & TFN & & TFN & & TFN & \\
\hline $\mathrm{T}$ & 1 & 1 & 1 & 0.33 & 0.5 & 1 & 1 & 2 & 3 \\
$\mathrm{P}$ & 1 & 2 & 3 & 1 & 1 & 1 & 1 & 2 & 3 \\
$\mathrm{E}$ & 0.33 & 0.5 & 1 & 0.33 & 0.5 & 1 & 1 & 1 & 1 \\
\hline
\end{tabular}

With regard to the selection of the most suitable underground mining method in the present case study, the technical and production criteria were given a slight advantage over the economic criterion. Then the subcriteria were evaluated. Given that each criterion was subdivided into a number of subcriteria (Table 2), this step involved the determination of the importance of all the subcriteria in a group, relative to each of the criteria. Table 4 shows the technical subcriteria scores. The relative weights of the technical subcriteria are presented in Table A1 (Appendix A).

Table 4. Evaluation of technical subcriteria.

\begin{tabular}{|c|c|c|c|c|c|c|c|c|c|c|c|c|}
\hline & \multicolumn{3}{|c|}{$\mathbf{T}_{1}$} & \multicolumn{3}{|c|}{$\mathbf{T}_{2}$} & \multicolumn{3}{|c|}{$\mathbf{T}_{3}$} & \multicolumn{3}{|c|}{$\mathrm{T}_{4}$} \\
\hline & \multicolumn{3}{|c|}{ TFN } & \multicolumn{3}{|c|}{ TFN } & \multicolumn{3}{|c|}{ TFN } & \multicolumn{3}{|c|}{ TFN } \\
\hline $\mathrm{T}_{1}$ & 1 & 1 & 1 & 3 & 4 & 5 & 7 & 8 & 9 & 1 & 3 & 5 \\
\hline $\mathrm{T}_{2}$ & 0.2 & 0.25 & 0.33 & 1 & 1 & 1 & 7 & 9 & 9 & 1 & 2 & 3 \\
\hline $\mathrm{T}_{3}$ & 0.11 & 0.125 & 0.14 & 0.11 & 0.11 & 0.14 & 1 & 1 & 1 & 1 & 2 & 3 \\
\hline $\mathrm{T}_{4}$ & 0.2 & 0.33 & 1 & 0.33 & 0.5 & 1 & 0.33 & 0.5 & 1 & 1 & 1 & 1 \\
\hline $\mathrm{T}_{5}$ & 0.2 & 0.25 & 0.33 & 0.14 & 0.2 & 0.33 & 3 & 5 & 7 & 0.14 & 0.166 & 0.2 \\
\hline $\mathrm{T}_{6}$ & 0.33 & 0.5 & 1 & 0.2 & 0.33 & 1 & 7 & 8 & 9 & 0.11 & 0.14 & 0.2 \\
\hline $\mathrm{T}_{7}$ & 0.11 & 0.14 & 0.2 & 0.11 & 0.14 & 0.2 & 7 & 8 & 9 & 0.11 & 0.14 & 0.2 \\
\hline $\mathrm{T}_{8}$ & 0.14 & 0.2 & 0.33 & 0.33 & 0.5 & 1 & 3 & 5 & 7 & 0.2 & 0.33 & 1 \\
\hline
\end{tabular}


Table 4. Cont.

\begin{tabular}{|c|c|c|c|c|c|c|c|c|c|c|c|c|}
\hline & \multicolumn{3}{|c|}{$\mathrm{T}_{5}$} & \multicolumn{3}{|c|}{$\mathrm{T}_{6}$} & \multicolumn{3}{|c|}{$\mathbf{T}_{7}$} & \multicolumn{3}{|c|}{$\mathrm{T}_{8}$} \\
\hline & \multicolumn{3}{|c|}{ TFN } & \multicolumn{3}{|c|}{ TFN } & \multicolumn{3}{|c|}{ TFN } & \multicolumn{3}{|c|}{ TFN } \\
\hline $\mathrm{T}_{1}$ & 3 & 4 & 5 & 1 & 2 & 3 & 5 & 7 & 9 & 3 & 5 & 7 \\
\hline $\mathrm{T}_{2}$ & 3 & 5 & 7 & 1 & 3 & 5 & 5 & 7 & 9 & 1 & 2 & 3 \\
\hline $\mathrm{T}_{3}$ & 0.14 & 0.2 & 0.33 & 0.11 & 0.125 & 0.14 & 0.11 & 0.125 & 0.14 & 0.14 & 0.2 & 0.33 \\
\hline $\mathrm{T}_{4}$ & 5 & 6 & 7 & 5 & 7 & 9 & 5 & 7 & 9 & 1 & 3 & 5 \\
\hline $\mathrm{T}_{5}$ & 1 & 1 & 1 & 0.14 & 0.2 & 0.33 & 1 & 3 & 5 & 0.14 & 0.2 & 0.33 \\
\hline $\mathrm{T}_{6}$ & 3 & 5 & 7 & 1 & 1 & 1 & 7 & 9 & 9 & 1 & 2 & 3 \\
\hline $\mathrm{T}_{7}$ & 0.2 & 0.33 & 1 & 0.11 & 0.11 & 0.14 & 1 & 1 & 1 & 0.2 & 0.25 & 0.33 \\
\hline $\mathrm{T}_{8}$ & 3 & 5 & 7 & 0.33 & 0.5 & 1 & 3 & 4 & 5 & 1 & 1 & 1 \\
\hline
\end{tabular}

Among the technical subcriteria, the most important were $T_{1}$ —ore body depth and $T_{2}$-ore body thickness, which were given a slight advantage over the other subcriteria, per the FAHP scale.

Table 5 shows the relative scores of the production subcriteria. The relative weight of each subcriterion in the form of a fuzzy number is presented in Table A2 (Appendix A). Among the production subcriteria, a slight advantage, per the FAHP scale, was given to $P_{2}$-safety at work, $P_{3}$ —environmental impact, and $P_{6}$-ventilation.

Table 5. Evaluation of production criteria.

\begin{tabular}{|c|c|c|c|c|c|c|c|c|c|c|c|c|c|c|c|c|c|c|c|c|c|}
\hline \multirow{2}{*}{ Cr. } & \multicolumn{3}{|c|}{ P1 } & \multicolumn{3}{|c|}{ P2 } & \multicolumn{3}{|c|}{ P3 } & \multicolumn{3}{|c|}{ P4 } & \multicolumn{3}{|c|}{$\mathbf{P}_{5}$} & \multicolumn{3}{|c|}{ P6 } & \multicolumn{3}{|c|}{ P7 } \\
\hline & & TFN & & & TFN & & & TFN & & & TFN & & & TFN & & & TFN & & & TFN & \\
\hline$P_{1}$ & 1 & 1 & 1 & 0.2 & 0.25 & 0.33 & 0.2 & 0.33 & 1 & 0.33 & 0.5 & 1 & 1 & 3 & 5 & 0.33 & 0.5 & 1 & 3 & 4 & 5 \\
\hline $\mathrm{P}_{2}$ & 3 & 4 & 5 & 1 & 1 & 1 & 3 & 4 & 5 & 3 & 5 & 7 & 1 & 3 & 5 & 1 & 2 & 3 & 3 & 4 & 5 \\
\hline $\mathrm{P}_{3}$ & 1 & 3 & 5 & 0.2 & 0.25 & 0.33 & 1 & 1 & 1 & 1 & 3 & 5 & 1 & 2 & 3 & 1 & 3 & 5 & 1 & 2 & 3 \\
\hline $\mathrm{P}_{4}$ & 1 & 2 & 3 & 0.14 & 0.2 & 0.33 & 0.2 & 0.33 & 1 & 1 & 1 & 1 & 0.2 & 0.33 & 1 & 0.2 & 0.25 & 0.33 & 1 & 2 & 3 \\
\hline$P_{5}$ & 0.2 & 0.33 & 1 & 0.2 & 0.33 & 1 & 0.33 & 0.5 & 1 & 1 & 3 & 5 & 1 & 1 & 1 & 0.2 & 0.33 & 1 & 1 & 2 & 3 \\
\hline $\mathrm{P}_{6}$ & 1 & 2 & 3 & 0.33 & 0.5 & 1 & 0.2 & 0.33 & 1 & 3 & 4 & 5 & 1 & 3 & 5 & 1 & 1 & 1 & 1 & 3 & 5 \\
\hline
\end{tabular}

Table 6 shows the relative scores of the economic subcriteria. The relative weight of each subcriterion in the form of a fuzzy number is presented in Table A3 (Appendix A).

Table 6. Evaluation of economic subcriteria.

\begin{tabular}{|c|c|c|c|c|c|c|c|c|c|}
\hline \multirow{2}{*}{ Cr. } & \multicolumn{3}{|c|}{$E_{1}$} & \multicolumn{3}{|c|}{$E_{2}$} & \multicolumn{3}{|c|}{$E_{3}$} \\
\hline & \multicolumn{3}{|c|}{ TFN } & \multicolumn{3}{|c|}{ TFN } & \multicolumn{3}{|c|}{ TFN } \\
\hline $\mathrm{E}_{1}$ & 1 & 1 & 1 & 0.33 & 0.5 & 1 & 0.2 & 0.33 & 1 \\
\hline$E_{2}$ & 1 & 2 & 3 & 1 & 1 & 1 & 1 & 3 & 5 \\
\hline$E_{3}$ & 1 & 3 & 5 & 0.2 & 0.33 & 1 & 1 & 1 & 1 \\
\hline
\end{tabular}

The alternatives were evaluated in the next step, by pairwise comparison relative to each subcriterion. This involved 18 comparisons. The results are shown in Tables 7-9. The respective calculated weight vectors are presented in Tables A4-A6 (Appendix A), based on the fuzzy extent analysis applying Equation (4) through (7).

Table A7 (Appendix A) shows (per step (d)) the ultimate weights of the subcriteria, calculated applying the aggregation principle according to Equation (8). The triangular fuzzy numbers of the criterion weights were multiplied by the weights of their subcriteria calculated in the previous step (c). Hence, one tier was eliminated from the criteria-subcriteria-alternatives hierarchy.

Then, using the equations described in step $\boldsymbol{e}$, the fuzzy decision matrix was calculated for the five alternatives (Equation (5)), as was the fuzzy performance matrix (Equation (10)), which represented the overall performance of each alternative relative to all the subcriteria. It was a result of multiplying all the subcriteria weights by the elements of the decision matrix (Table A8, Appendix A). 
Table 7. Evaluation of alternatives relative to technical subcriteria.

\begin{tabular}{|c|c|c|c|c|c|c|c|c|c|c|c|c|c|c|c|}
\hline \multirow{2}{*}{$\mathrm{T}_{1}$} & \multicolumn{3}{|c|}{$\mathbf{A}_{1}$} & \multicolumn{3}{|c|}{$\mathbf{A}_{2}$} & \multicolumn{3}{|c|}{$\mathbf{A}_{3}$} & \multicolumn{3}{|c|}{$\mathbf{A}_{4}$} & \multicolumn{3}{|c|}{$\mathbf{A}_{5}$} \\
\hline & \multicolumn{3}{|c|}{ TFN } & \multicolumn{3}{|c|}{ TFN } & \multicolumn{3}{|c|}{ TFN } & \multicolumn{3}{|c|}{ TFN } & \multicolumn{3}{|c|}{ TFN } \\
\hline $\mathrm{A}_{1}$ & 1 & 1 & 1 & 0.2 & 0.33 & 1 & 0.2 & 0.33 & 1 & 1 & 2 & 3 & 0.2 & 0.33 & 1 \\
\hline $\mathrm{A}_{2}$ & 1 & 3 & 5 & 1 & 1 & 1 & 1 & 2 & 3 & 7 & 9 & 9 & 3 & 4 & 5 \\
\hline $\mathrm{A}_{3}$ & 1 & 3 & 5 & 0.33 & 0.5 & 1 & 1 & 1 & 1 & 5 & 6 & 7 & 1 & 3 & 5 \\
\hline $\mathrm{A}_{4}$ & 0.33 & 0.5 & 1 & 0.11 & 0.11 & 0.14 & 0.14 & 0.166 & 0.2 & 1 & 1 & 1 & 0.14 & 0.2 & 0.33 \\
\hline $\mathrm{A}_{5}$ & 1 & 3 & 5 & 0.2 & 0.25 & 0.33 & 0.2 & 0.33 & 1 & 3 & 5 & 7 & 1 & 1 & 1 \\
\hline \multirow{2}{*}{$\mathbf{T}_{2}$} & \multicolumn{3}{|c|}{$\mathbf{A}_{1}$} & & $\mathbf{A}_{2}$ & & & $\mathbf{A}_{3}$ & & & $\mathbf{A}_{4}$ & & & $\mathbf{A}_{5}$ & \\
\hline & & TFN & & & TFN & & & TFN & & & TFN & & & TFN & \\
\hline $\mathrm{A}_{1}$ & 1 & 1 & 1 & 7 & 9 & 9 & 3 & 4 & 5 & 1 & 3 & 5 & 1 & 2 & 3 \\
\hline $\mathrm{A}_{2}$ & 0.11 & 0.11 & 0.14 & 1 & 1 & 1 & 0.2 & 0.25 & 0.33 & 0.2 & 0.33 & 1 & 0.2 & 0.25 & 0.33 \\
\hline$A_{3}$ & 0.2 & 0.25 & 0.33 & 3 & 4 & 5 & 1 & 1 & 1 & 1 & 3 & 5 & 0.2 & 0.25 & 0.33 \\
\hline $\mathrm{A}_{4}$ & 0.2 & 0.33 & 1 & 1 & 3 & 5 & 0.2 & 0.33 & 1 & 1 & 1 & 1 & 0.2 & 0.33 & 1 \\
\hline $\mathrm{A}_{5}$ & 0.33 & 0.5 & 1 & 3 & 4 & 5 & 3 & 4 & 5 & 1 & 3 & 5 & 1 & 1 & 1 \\
\hline$T_{3}$ & & $\mathbf{A}_{1}$ & & & $\mathbf{A}_{2}$ & & & $\mathbf{A}_{3}$ & & & $\mathbf{A}_{4}$ & & & $\mathbf{A}_{5}$ & \\
\hline & & TFN & & & TFN & & & TFN & & & TFN & & & TFN & \\
\hline $\mathrm{A}_{1}$ & 1 & 1 & 1 & 1 & 3 & 5 & 3 & 4 & 5 & 7 & 9 & 9 & 3 & 4 & 5 \\
\hline $\mathrm{A}_{2}$ & 0.2 & 0.33 & 1 & 1 & 1 & 1 & 1 & 3 & 5 & 3 & 5 & 7 & 1 & 3 & 5 \\
\hline $\mathrm{A}_{3}$ & 0.2 & 0.25 & 0.33 & 0.2 & 0.33 & 1 & 1 & 1 & 1 & 1 & 3 & 5 & 0.33 & 0.5 & 1 \\
\hline $\mathrm{A}_{4}$ & 0.11 & 0.11 & 0.14 & 0.14 & 0.2 & 0.33 & 0.2 & 0.33 & 1 & 1 & 1 & 1 & 0.2 & 0.25 & 0.33 \\
\hline $\mathrm{A}_{5}$ & 0.2 & 0.25 & 0.33 & 0.2 & 0.33 & 1 & 1 & 2 & 3 & 3 & 4 & 5 & 1 & 1 & 1 \\
\hline $\mathrm{T}_{4}$ & & $\mathbf{A}_{1}$ & & & $\mathbf{A}_{2}$ & & & $\mathbf{A}_{3}$ & & & $\mathbf{A}_{4}$ & & & $\mathbf{A}_{5}$ & \\
\hline & & TFN & & & TFN & & & TFN & & & TFN & & & TFN & \\
\hline $\mathrm{A}_{1}$ & 1 & 1 & 1 & 3 & 5 & 7 & 1 & 3 & 5 & 3 & 4 & 5 & 0.33 & 0.5 & 1 \\
\hline $\mathrm{A}_{2}$ & 0.14 & 0.2 & 0.33 & 1 & 1 & 1 & 0.2 & 0.33 & 1 & 0.33 & 0.5 & 1 & 0.11 & 0.11 & 0.14 \\
\hline$A_{3}$ & 0.2 & 0.33 & 1 & 1 & 3 & 5 & 1 & 1 & 1 & 1 & 3 & 5 & 0.2 & 0.25 & 0.33 \\
\hline $\mathrm{A}_{4}$ & 0.2 & 0.25 & 0.33 & 1 & 2 & 3 & 0.2 & 0.33 & 1 & 1 & 1 & 1 & 0.14 & 0.2 & 0.33 \\
\hline $\mathrm{A}_{5}$ & 1 & 2 & 3 & 7 & 9 & 9 & 3 & 4 & 5 & 3 & 5 & 7 & 1 & 1 & 1 \\
\hline$T_{5}$ & & $\mathbf{A}_{1}$ & & & $\mathbf{A}_{2}$ & & & $\mathbf{A}_{3}$ & & & $\mathbf{A}_{4}$ & & & $\mathbf{A}_{5}$ & \\
\hline & & TFN & & & TFN & & & TFN & & & TFN & & & TFN & \\
\hline $\mathrm{A}_{1}$ & 1 & 1 & 1 & 1 & 3 & 5 & 7 & 9 & 9 & 5 & 6 & 7 & 1 & 2 & 3 \\
\hline $\mathrm{A}_{2}$ & 0.2 & 0.33 & 1 & 1 & 1 & 1 & 3 & 4 & 5 & 1 & 3 & 5 & 1 & 3 & 5 \\
\hline $\mathrm{A}_{3}$ & 0.11 & 0.11 & 0.14 & 0.2 & 0.25 & 0.33 & 1 & 1 & 1 & 0.2 & 0.33 & 1 & 0.2 & 0.25 & 0.33 \\
\hline $\mathrm{A}_{4}$ & 0.14 & 0.166 & 0.2 & 0.2 & 0.33 & 1 & 1 & 3 & 5 & 1 & 1 & 1 & 0.2 & 0.25 & 0.33 \\
\hline $\mathrm{A}_{5}$ & 0.33 & 0.5 & 1 & 0.2 & 0.33 & 1 & 3 & 4 & 5 & 3 & 4 & 5 & 1 & 1 & 1 \\
\hline$T_{6}$ & & $\mathbf{A}_{1}$ & & & $\mathbf{A}_{2}$ & & & $\mathbf{A}_{3}$ & & & $\mathbf{A}_{4}$ & & & $\mathbf{A}_{5}$ & \\
\hline & & TFN & & & TFN & & & TFN & & & TFN & & & TFN & \\
\hline $\mathrm{A}_{1}$ & 1 & 1 & 1 & 0.2 & 0.33 & 1 & 1 & 3 & 5 & 3 & 4 & 5 & 0.2 & 0.33 & 1 \\
\hline $\mathrm{A}_{2}$ & 1 & 3 & 5 & 1 & 1 & 1 & 3 & 5 & 7 & 7 & 9 & 9 & 1 & 2 & 3 \\
\hline $\mathrm{A}_{3}$ & 0.2 & 0.33 & 1 & 0.14 & 0.2 & 0.33 & 1 & 1 & 1 & 1 & 3 & 5 & 0.2 & 0.25 & 0.33 \\
\hline $\mathrm{A}_{4}$ & 0.2 & 0.25 & 0.33 & 0.11 & 0.11 & 0.14 & 0.2 & 0.33 & 1 & 1 & 1 & 1 & 0.2 & 0.25 & 0.33 \\
\hline $\mathrm{A}_{5}$ & 1 & 3 & 5 & 0.33 & 0.5 & 1 & 3 & 4 & 5 & 3 & 4 & 5 & 1 & 1 & 1 \\
\hline$T_{7}$ & & $\mathbf{A}_{1}$ & & & $\mathbf{A}_{2}$ & & & $\mathbf{A}_{3}$ & & & $\mathbf{A}_{4}$ & & & $\mathbf{A}_{5}$ & \\
\hline & & TFN & & & TFN & & & TFN & & & TFN & & & TFN & \\
\hline $\mathrm{A}_{1}$ & 1 & 1 & 1 & 0.2 & 0.25 & 0.33 & 0.2 & 0.33 & 1 & 0.11 & 0.11 & 0.14 & 0.33 & 0.5 & 1 \\
\hline $\mathrm{A}_{2}$ & 3 & 4 & 5 & 1 & 1 & 1 & 1 & 2 & 3 & 0.33 & 0.5 & 1 & 3 & 4 & 5 \\
\hline $\mathrm{A}_{3}$ & 1 & 3 & 5 & 0.33 & 0.5 & 1 & 1 & 1 & 1 & 0.2 & 0.33 & 1 & 1 & 3 & 5 \\
\hline $\mathrm{A}_{4}$ & 7 & 9 & 9 & 1 & 2 & 3 & 1 & 3 & 5 & 1 & 1 & 1 & 3 & 5 & 7 \\
\hline $\mathrm{A}_{5}$ & 1 & 2 & 3 & 0.2 & 0.25 & 0.33 & 0.2 & 0.33 & 1 & 0.14 & 0.2 & 0.33 & 1 & 1 & 1 \\
\hline$T_{8}$ & & $\mathbf{A}_{1}$ & & & $\mathbf{A}_{2}$ & & & $\mathbf{A}_{3}$ & & & $\mathbf{A}_{4}$ & & & $\mathbf{A}_{5}$ & \\
\hline & & TFN & & & TFN & & & TFN & & & TFN & & & TFN & \\
\hline $\mathrm{A}_{1}$ & 1 & 1 & 1 & 0.14 & 0.166 & 0.2 & 1 & 3 & 5 & 0.2 & 0.25 & 0.33 & 0.2 & 0.33 & 1 \\
\hline $\mathrm{A}_{2}$ & 5 & 6 & 7 & 1 & 1 & 1 & 7 & 9 & 9 & 1 & 2 & 3 & 1 & 3 & 5 \\
\hline $\mathrm{A}_{3}$ & 0.2 & 0.33 & 1 & 0.11 & 0.11 & 0.14 & 1 & 1 & 1 & 0.2 & 0.25 & 0.33 & 0.2 & 0.25 & 0.33 \\
\hline $\mathrm{A}_{4}$ & 3 & 4 & 5 & 0.33 & 0.5 & 1 & 3 & 4 & 5 & 1 & 1 & 1 & 1 & 3 & 5 \\
\hline $\mathrm{A}_{5}$ & 1 & 3 & 5 & 0.2 & 0.33 & 1 & 3 & 4 & 5 & 0.2 & 0.33 & 1 & 1 & 1 & 1 \\
\hline
\end{tabular}


Table 8. Evaluation of alternatives relative to production subcriteria.

\begin{tabular}{|c|c|c|c|c|c|c|c|c|c|c|c|c|c|c|c|}
\hline \multirow{2}{*}{$\mathbf{P}_{1}$} & \multicolumn{3}{|c|}{$\mathbf{A}_{1}$} & \multicolumn{3}{|c|}{$\mathbf{A}_{2}$} & \multicolumn{3}{|c|}{$\mathbf{A}_{3}$} & \multicolumn{3}{|c|}{$\mathbf{A}_{4}$} & \multicolumn{3}{|c|}{$\mathbf{A}_{5}$} \\
\hline & \multicolumn{3}{|c|}{ TFN } & \multicolumn{3}{|c|}{ TFN } & \multicolumn{3}{|c|}{ TFN } & \multicolumn{3}{|c|}{ TFN } & \multicolumn{3}{|c|}{ TFN } \\
\hline $\mathrm{A}_{1}$ & 1 & 1 & 1 & 3 & 4 & 5 & 1 & 3 & 5 & 3 & 4 & 5 & 0.33 & 0.5 & 1 \\
\hline $\mathrm{A}_{2}$ & 0.2 & 0.25 & 0.33 & 1 & 1 & 1 & 0.2 & 0.25 & 0.33 & 0.33 & 0.5 & 1 & 0.11 & 0.11 & 0.14 \\
\hline $\mathrm{A}_{3}$ & 0.2 & 0.33 & 1 & 3 & 4 & 5 & 1 & 1 & 1 & 1 & 3 & 5 & 0.2 & 0.25 & 0.33 \\
\hline $\mathrm{A}_{4}$ & 0.2 & 0.25 & 0.33 & 1 & 2 & 3 & 0.2 & 0.33 & 1 & 1 & 1 & 1 & 0.14 & 0.2 & 0.33 \\
\hline $\mathrm{A}_{5}$ & 1 & 2 & 3 & 7 & 9 & 9 & 3 & 4 & 5 & 3 & 5 & 7 & 1 & 1 & 1 \\
\hline \multirow{2}{*}{$\mathbf{P}_{2}$} & \multicolumn{3}{|c|}{$\mathbf{A}_{1}$} & \multicolumn{3}{|c|}{$\mathbf{A}_{2}$} & \multicolumn{3}{|c|}{$\mathbf{A}_{3}$} & \multicolumn{3}{|c|}{$\mathbf{A}_{4}$} & \multicolumn{3}{|c|}{$\mathbf{A}_{5}$} \\
\hline & & TFN & & & TFN & & & TFN & & & TFN & & & TFN & \\
\hline $\mathrm{A}_{1}$ & 1 & 1 & 1 & 1 & 3 & 5 & 3 & 5 & 7 & 5 & 6 & 7 & 0.2 & 0.33 & 1 \\
\hline $\mathrm{A}_{2}$ & 0.2 & 0.33 & 1 & 1 & 1 & 1 & 1 & 3 & 5 & 3 & 4 & 5 & 0.2 & 0.25 & 0.33 \\
\hline$A_{3}$ & 0.14 & 0.2 & 0.33 & 0.2 & 0.33 & 1 & 1 & 1 & 1 & 1 & 2 & 3 & 0.14 & 0.166 & 0.2 \\
\hline $\mathrm{A}_{4}$ & 0.14 & 0.166 & 0.2 & 0.2 & 0.25 & 0.33 & 0.33 & 0.5 & 1 & 1 & 1 & 1 & 0.11 & 0.11 & 0.14 \\
\hline $\mathrm{A}_{5}$ & 1 & 3 & 5 & 3 & 4 & 5 & 5 & 6 & 7 & 7 & 9 & 9 & 1 & 1 & 1 \\
\hline$P_{3}$ & & $\mathbf{A}_{1}$ & & & $\mathbf{A}_{2}$ & & & $\mathbf{A}_{3}$ & & & $\mathbf{A}_{4}$ & & & $\mathbf{A}_{5}$ & \\
\hline & & TFN & & & TFN & & & TFN & & & TFN & & & TFN & \\
\hline $\mathrm{A}_{1}$ & 1 & 1 & 1 & 0.11 & 0.11 & 0.14 & 0.2 & 0.25 & 0.33 & 0.14 & 0.2 & 0.33 & 0.33 & 0.5 & 1 \\
\hline $\mathrm{A}_{2}$ & 7 & 9 & 9 & 1 & 1 & 1 & 3 & 4 & 5 & 1 & 2 & 3 & 5 & 6 & 7 \\
\hline $\mathrm{A}_{3}$ & 3 & 4 & 5 & 0.2 & 0.25 & 0.33 & 1 & 1 & 1 & 0.33 & 0.5 & 1 & 1 & 2 & 3 \\
\hline $\mathrm{A}_{4}$ & 3 & 5 & 7 & 0.33 & 0.5 & 1 & 1 & 2 & 3 & 1 & 1 & 1 & 3 & 4 & 5 \\
\hline $\mathrm{A}_{5}$ & 1 & 2 & 3 & 0.14 & 0.166 & 0.2 & 0.33 & 0.5 & 1 & 0.2 & 0.25 & 0.33 & 1 & 1 & 1 \\
\hline $\mathbf{P}_{4}$ & & $\mathbf{A}_{1}$ & & & $\mathbf{A}_{\mathbf{2}}$ & & & $\mathbf{A}_{3}$ & & & $\mathbf{A}_{4}$ & & & $\mathbf{A}_{5}$ & \\
\hline & & TFN & & & TFN & & & TFN & & & TFN & & & TFN & \\
\hline $\mathrm{A}_{1}$ & 1 & 1 & 1 & 0.14 & 0.166 & 0.2 & 0.2 & 0.33 & 1 & 0.33 & 0.5 & 1 & 0.2 & 0.33 & 1 \\
\hline $\mathrm{A}_{2}$ & 5 & 6 & 7 & 1 & 1 & 1 & 3 & 4 & 5 & 7 & 9 & 9 & 1 & 3 & 5 \\
\hline $\mathrm{A}_{3}$ & 1 & 3 & 5 & 0.2 & 0.25 & 0.33 & 1 & 1 & 1 & 3 & 4 & 5 & 0.2 & 0.33 & 1 \\
\hline $\mathrm{A}_{4}$ & 1 & 2 & 3 & 0.11 & 0.11 & 0.14 & 0.2 & 0.25 & 0.33 & 1 & 1 & 1 & 0.14 & 0.2 & 0.33 \\
\hline $\mathrm{A}_{5}$ & 1 & 3 & 5 & 0.2 & 0.33 & 1 & 1 & 3 & 5 & 3 & 5 & 7 & 1 & 1 & 1 \\
\hline$P_{5}$ & & $\mathbf{A}_{1}$ & & & $\mathbf{A}_{2}$ & & & $\mathbf{A}_{3}$ & & & $\mathbf{A}_{4}$ & & & $\mathbf{A}_{5}$ & \\
\hline & & TFN & & & TFN & & & TFN & & & TFN & & & TFN & \\
\hline $\mathrm{A}_{1}$ & 1 & 1 & 1 & 0.11 & 0.11 & 0.14 & 0.2 & 0.33 & 1 & 0.2 & 0.25 & 0.33 & 0.14 & 0.2 & 0.33 \\
\hline $\mathrm{A}_{2}$ & 7 & 9 & 9 & 1 & 1 & 1 & 5 & 6 & 7 & 1 & 3 & 5 & 1 & 2 & 3 \\
\hline $\mathrm{A}_{3}$ & 1 & 3 & 5 & 0.14 & 0.166 & 0.2 & 1 & 1 & 1 & 0.33 & 0.5 & 1 & 0.2 & 0.33 & 1 \\
\hline $\mathrm{A}_{4}$ & 3 & 4 & 5 & 0.2 & 0.33 & 1 & 1 & 2 & 3 & 1 & 1 & 1 & 0.2 & 0.33 & 1 \\
\hline $\mathrm{A}_{5}$ & 3 & 5 & 7 & 0.33 & 0.5 & 1 & 1 & 3 & 5 & 1 & 3 & 5 & 1 & 1 & 1 \\
\hline$P_{6}$ & & $\mathbf{A}_{1}$ & & & $\mathbf{A}_{2}$ & & & $\mathbf{A}_{3}$ & & & $\mathbf{A}_{4}$ & & & $\mathbf{A}_{5}$ & \\
\hline & & TFN & & & TFN & & & TFN & & & TFN & & & TFN & \\
\hline $\mathrm{A}_{1}$ & 1 & 1 & 1 & 0.2 & 0.25 & 0.33 & 0.11 & 0.11 & 0.14 & 0.14 & 0.2 & 0.33 & 0.33 & 0.5 & 1 \\
\hline $\mathrm{A}_{2}$ & 3 & 4 & 5 & 1 & 1 & 1 & 0.2 & 0.25 & 0.33 & 0.2 & 0.25 & 0.33 & 1 & 2 & 3 \\
\hline $\mathrm{A}_{3}$ & 7 & 9 & 9 & 3 & 4 & 5 & 1 & 1 & 1 & 1 & 3 & 5 & 5 & 6 & 7 \\
\hline $\mathrm{A}_{4}$ & 3 & 5 & 7 & 3 & 4 & 5 & 0.2 & 0.33 & 1 & 1 & 1 & 1 & 3 & 4 & 5 \\
\hline $\mathrm{A}_{5}$ & 1 & 2 & 3 & 0.33 & 0.5 & 1 & 0.14 & 0.166 & 0.2 & 0.2 & 0.25 & 0.33 & 1 & 1 & 1 \\
\hline$P_{7}$ & & $\mathbf{A}_{1}$ & & & $\mathbf{A}_{2}$ & & & $\mathbf{A}_{3}$ & & & $\mathbf{A}_{4}$ & & & $\mathbf{A}_{5}$ & \\
\hline & & TFN & & & TFN & & & TFN & & & TFN & & & TFN & \\
\hline $\mathrm{A}_{1}$ & 1 & 1 & 1 & 0.11 & 0.11 & 0.14 & 0.2 & 0.25 & 0.33 & 0.14 & 0.166 & 0.2 & 0.2 & 0.33 & 1 \\
\hline $\mathrm{A}_{2}$ & 7 & 9 & 9 & 1 & 1 & 1 & 3 & 4 & 5 & 1 & 3 & 5 & 5 & 6 & 7 \\
\hline $\mathrm{A}_{3}$ & 3 & 4 & 5 & 0.2 & 0.25 & 0.33 & 1 & 1 & 1 & 0.2 & 0.33 & 1 & 1 & 3 & 5 \\
\hline $\mathrm{A}_{4}$ & 5 & 6 & 7 & 0.2 & 0.33 & 1 & 1 & 3 & 5 & 1 & 1 & 1 & 3 & 4 & 5 \\
\hline $\mathrm{A}_{5}$ & 1 & 3 & 5 & 0.14 & 0.166 & 0.2 & 0.2 & 0.33 & 1 & 0.2 & 0.25 & 0.33 & 1 & 1 & 1 \\
\hline
\end{tabular}


Table 9. Evaluation of alternatives relative to economic subcriteria.

\begin{tabular}{|c|c|c|c|c|c|c|c|c|c|c|c|c|c|c|c|}
\hline \multirow{2}{*}{$\mathrm{E}_{1}$} & \multicolumn{3}{|c|}{$\mathbf{A}_{1}$} & \multicolumn{3}{|c|}{$\mathbf{A}_{2}$} & \multicolumn{3}{|c|}{$\mathbf{A}_{3}$} & \multicolumn{3}{|c|}{$\mathbf{A}_{4}$} & \multicolumn{3}{|c|}{$\mathbf{A}_{5}$} \\
\hline & \multicolumn{3}{|c|}{ TFN } & \multicolumn{3}{|c|}{ TFN } & \multicolumn{3}{|c|}{ TFN } & \multicolumn{3}{|c|}{ TFN } & \multicolumn{3}{|c|}{ TFN } \\
\hline $\mathrm{A}_{1}$ & 1 & 1 & 1 & 1 & 2 & 3 & 0.2 & 0.33 & 1 & 0.14 & 0.166 & 0.2 & 0.2 & 0.33 & 1 \\
\hline $\mathrm{A}_{2}$ & 0.33 & 0.5 & 1 & 1 & 1 & 1 & 0.2 & 0.25 & 0.33 & 0.11 & 0.11 & 0.14 & 0.2 & 0.25 & 0.33 \\
\hline $\mathrm{A}_{3}$ & 1 & 3 & 5 & 3 & 4 & 5 & 1 & 1 & 1 & 0.2 & 0.33 & 1 & 1 & 3 & 5 \\
\hline $\mathrm{A}_{4}$ & 5 & 6 & 7 & 7 & 9 & 9 & 1 & 3 & 5 & 1 & 1 & 1 & 3 & 4 & 5 \\
\hline $\mathrm{A}_{5}$ & 1 & 3 & 5 & 3 & 4 & 5 & 0.2 & 0.33 & 1 & 0.2 & 0.25 & 0.33 & 1 & 1 & 1 \\
\hline \multirow{2}{*}{$E_{2}$} & \multicolumn{3}{|c|}{$\mathbf{A}_{1}$} & \multicolumn{3}{|c|}{$\mathbf{A}_{2}$} & \multicolumn{3}{|c|}{$\mathbf{A}_{3}$} & \multicolumn{3}{|c|}{$\mathbf{A}_{4}$} & \multicolumn{3}{|c|}{$\mathbf{A}_{5}$} \\
\hline & \multicolumn{3}{|c|}{ TFN } & \multicolumn{3}{|c|}{ TFN } & \multicolumn{3}{|c|}{ TFN } & \multicolumn{3}{|c|}{ TFN } & \multicolumn{3}{|c|}{ TFN } \\
\hline $\mathrm{A}_{1}$ & 1 & 1 & 1 & 3 & 4 & 5 & 1 & 3 & 5 & 1 & 3 & 5 & 0.2 & 0.33 & 1 \\
\hline $\mathrm{A}_{2}$ & 0.2 & 0.25 & 0.33 & 1 & 1 & 1 & 0.2 & 0.25 & 0.33 & 1 & 2 & 3 & 0.11 & 0.11 & 0.14 \\
\hline $\mathrm{A}_{3}$ & 0.2 & 0.33 & 1 & 3 & 4 & 5 & 1 & 1 & 1 & 1 & 2 & 3 & 0.2 & 0.25 & 0.33 \\
\hline $\mathrm{A}_{4}$ & 0.2 & 0.33 & 1 & 0.33 & 0.5 & 1 & 0.33 & 0.5 & 1 & 1 & 1 & 1 & 0.14 & 0.166 & 0.2 \\
\hline $\mathrm{A}_{5}$ & 1 & 3 & 5 & 7 & 9 & 9 & 3 & 4 & 5 & 5 & 6 & 7 & 1 & 1 & 1 \\
\hline \multirow{2}{*}{$E_{3}$} & \multicolumn{3}{|c|}{$\mathbf{A}_{1}$} & \multicolumn{3}{|c|}{$\mathbf{A}_{2}$} & \multicolumn{3}{|c|}{$\mathbf{A}_{3}$} & \multicolumn{3}{|c|}{$\mathbf{A}_{4}$} & \multicolumn{3}{|c|}{$\mathbf{A}_{5}$} \\
\hline & \multicolumn{3}{|c|}{ TFN } & \multicolumn{3}{|c|}{ TFN } & \multicolumn{3}{|c|}{ TFN } & & TFN & & & TFN & \\
\hline $\mathrm{A}_{1}$ & 1 & 1 & 1 & 7 & 9 & 9 & 3 & 4 & 5 & 5 & 6 & 7 & 1 & 2 & 3 \\
\hline $\mathrm{A}_{2}$ & 0.11 & 0.11 & 0.14 & 1 & 1 & 1 & 0.2 & 0.25 & 0.33 & 0.33 & 0.5 & 1 & 0.14 & 0.2 & 0.33 \\
\hline $\mathrm{A}_{3}$ & 0.2 & 0.25 & 0.33 & 3 & 4 & 5 & 1 & 1 & 1 & 1 & 3 & 5 & 0.2 & 0.33 & 1 \\
\hline $\mathrm{A}_{4}$ & 0.14 & 0.166 & 0.2 & 1 & 2 & 3 & 0.2 & 0.33 & 1 & 1 & 1 & 1 & 0.2 & 0.25 & 0.33 \\
\hline $\mathrm{A}_{5}$ & 0.33 & 0.5 & 1 & 3 & 5 & 7 & 1 & 3 & 5 & 3 & 4 & 5 & 1 & 1 & 1 \\
\hline
\end{tabular}

Per steps $f$ and $g$, Tables 10 and 11 show the ultimate scores of the five alternatives in the form of fuzzy numbers, obtained by adding the fuzzy numbers-elements of the fuzzy performance matrix, according to Equation (11). Then the ultimate weights of the alternatives are shown in the form of non-fuzzy numbers, after defuzzification employing Equation (12). The final ranking of the alternatives is based on the sensitivity analysis per Equation (13). Figure 4 shows the total integral value of moderate, pessimistic and optimistic experts' risk assessments, or the weights of the alternatives relative to the optimization index parameters. If the decision-maker's inclination is optimistic $(\alpha=1)$, the weights of the alternatives vary over a very narrow range, compared to pessimistic $(\alpha=0)$ and moderate $(\alpha=0.5)$. Based on the sensitivity analysis, the average differences between the weights of the alternatives were in the $0.1-0.73 \%$ range for an optimization index of 0.5 , and $0.75-7.8 \%$ for an optimization index of 0 . Defuzzification yielded the weights of the alternatives in the form of "normal" or real numbers. The highest weight is the best score. Based on the results, alternative 5 is the optimal underground mining method, followed in descending order by Alternative 2, Alternative 1, Alternative 3 and Alternative 4.

According to the MCDA model, Alternative 5 (VCR) was proposed as the optimal underground mining method for the Borska Reka copper mine. This method does not require extensive preparations, its productivity is high and the costs of mining are relatively low. There are also other advantages, such as a high ore utilization rate, low ore impoverishment, and a high level of safety at work, which was one of the most important evaluation factors in the case study. For all these reasons, the method proposed for the given copper mine provides optimal mining conditions.

Table 10. Ranking and optimal alternative.

\begin{tabular}{cccccc}
\hline & \multicolumn{2}{c}{ TFN } & & Real Number & Ranking \\
\hline $\mathrm{A}_{1}$ & 0.020 & 0.196 & 1.955 & 0.1978 & 3 \\
$\mathrm{~A}_{2}$ & 0.023 & 0.222 & 2.019 & 0.2048 & 2 \\
$\mathrm{~A}_{3}$ & 0.016 & 0.173 & 1.814 & 0.1833 & 4 \\
$\mathrm{~A}_{4}$ & 0.014 & 0.133 & 1.407 & 0.1421 & 5 \\
$\mathrm{~A}_{5}$ & 0.028 & 0.275 & 2.684 & 0.2717 & \\
\multicolumn{7}{c}{ Optimal alternative } & & & $\mathrm{A}_{5}$ & \\
\hline
\end{tabular}


Table 11. Sensitivity analysis.

\begin{tabular}{cccc}
\hline Alternatives & $\boldsymbol{\alpha}=\mathbf{0}$ & $\boldsymbol{\alpha}=\mathbf{0 . 5}$ & $\boldsymbol{\alpha}=\mathbf{1}$ \\
\hline $\mathrm{A}_{1}$ & 0.1962 & 0.1975 & 0.1977 \\
$\mathrm{~A}_{2}$ & 0.2220 & 0.2074 & 0.2059 \\
$\mathrm{~A}_{3}$ & 0.1724 & 0.1817 & 0.1826 \\
$\mathrm{~A}_{4}$ & 0.1339 & 0.1409 & 0.1416 \\
$\mathrm{~A}_{5}$ & 0.2752 & 0.2722 & 0.2719 \\
\hline
\end{tabular}

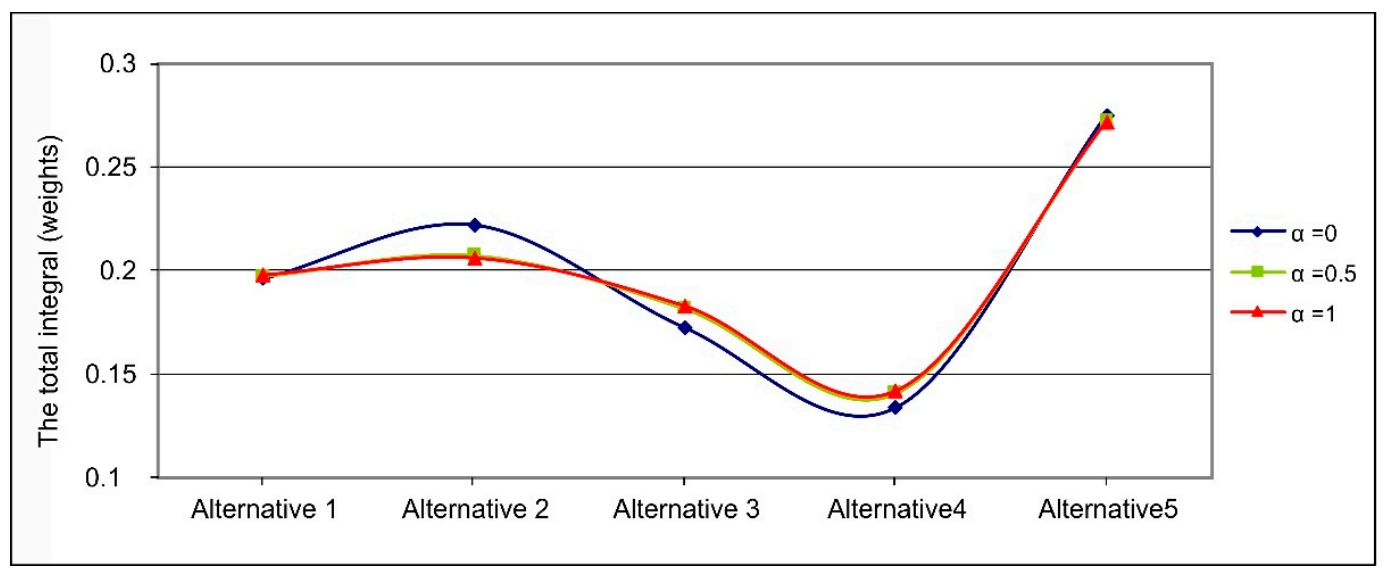

Figure 4. Total integral values of moderate, pessimistic and optimistic expert's risk assessments.

This procedure does not complete the analysis of the mining problem. Management support strategies are developed for the upcoming period of mining. Such strategies enable the management team to assume full professional responsibility for improving development plans. Additional future activities are defined to ensure mining efficiency and high productivity. This also includes the use of the latest technological achievements that help upgrade mining safety. On the one hand, the implementation of solutions and management team's commitment contribute to sustainable development of the entire process of mining operations, while on the other hand, they contribute to long-term stable technical, economic, and production conditions.

\section{Conclusions}

The paper demonstrated that FAHP is an extremely useful technique in the mining industry, given that the criteria used in the case study were subjective and based on expert judgment (of mining engineers and geologists), which is an important consideration in underground mining.

The research indicated that an interdisciplinary approach connects underground mining with other areas of science. For example, it links mining with fuzzy logic (based on mathematics and psychology) and multiple-criteria decision-making.

The paper described and analyzed in detail the factors that influence the selection of the optimal underground mining method, including (i) technical (ore body depth, ore body thickness, ore body shape, value of ore, ore body slope, rock hardness and stability, type of ore body and contact with neighboring rocks, and the mineral and chemical composition of the ore), (ii) production (productivity, capacity, safety at work, environmental impact, ore dilution, ore impoverishment, ventilation and hydrologic conditions), and (iii) economic (capital expenditure, costs of mining and costs of maintenance). These criteria, along with their subcriteria, are deemed to be universal and applicable to other underground mines.

The practical importance of the proposed methodology was demonstrated in a case study that included the evaluation of criteria, subcriteria and alternatives applying FAHP, and decision-making/selection of the optimal underground mining method. This reflects the primary academic contribution and implications for further research. 
In addition, the approach implemented fuzzy logic in multiple-criteria optimization related to underground mining. On the one hand, the objective of applying the fuzzy approach to decision-making and problem-solving in cases where there are several alternatives and analyzing the relevant factors is to arrive at the optimal solution. On the other hand, expert intuition and experience play an important role in the assessment of the ore system and underground mining methods, while fuzzy logic in mathematical calculations enables such a heuristic approach to problem solving. Such an interdisciplinary approach contributes to the quality and sustainable management of underground mining.

Author Contributions: All the authors jointly contributed to the finalization of the paper: S.B. designed the MCDM model and conducted optimization calculations; B.G. and V.R.V., along with S.B., analyzed the criteria and alternatives, and D.B. critically reviewed the concept and design of the paper. All authors have read and agreed to the published version of the manuscript.

Funding: This research received no external funding.

Acknowledgments: We express our gratitude to the Serbian Ministry of Education, Science and Technological Development, for funding projects TR33029, TR33003 and OI176022.

Conflicts of Interest: The authors declare no conflict of interest. The funders had no role in the design of the study; in the collection, analyses, or interpretation of data; in the writing of the manuscript, or in the decision to publish the results.

\section{Appendix A}

Table A1. Weights of technical subcriteria.

\begin{tabular}{cccc}
\hline Subcriteria & \multicolumn{3}{c}{ Weights (TFN) } \\
\hline $\mathrm{T}_{1}$ & 0.119 & 0.219 & 0.403 \\
$\mathrm{~T}_{2}$ & 0.095 & 0.188 & 0.342 \\
$\mathrm{~T}_{3}$ & 0.013 & 0.025 & 0.048 \\
$\mathrm{~T}_{4}$ & 0.088 & 0.163 & 0.312 \\
$\mathrm{~T}_{5}$ & 0.028 & 0.064 & 0.133 \\
$\mathrm{~T}_{6}$ & 0.097 & 0.167 & 0.286 \\
$\mathrm{~T}_{7}$ & 0.044 & 0.065 & 0.111 \\
$\mathrm{~T}_{8}$ & 0.054 & 0.106 & 0.214 \\
\hline
\end{tabular}

Table A2. Weights of production criteria.

\begin{tabular}{cccc}
\hline Subcriteria & \multicolumn{3}{c}{ Weights (TFN) } \\
\hline $\mathrm{P}_{1}$ & 0.052 & 0.112 & 0.318 \\
$\mathrm{P}_{2}$ & 0.128 & 0.300 & 0.688 \\
$\mathrm{P}_{3}$ & 0.053 & 0.186 & 0.495 \\
$\mathrm{P}_{4}$ & 0.032 & 0.079 & 0.214 \\
$\mathrm{P}_{5}$ & 0.033 & 0.097 & 0.288 \\
$\mathrm{P}_{6}$ & 0.064 & 0.180 & 0.466 \\
$\mathrm{P}_{7}$ & 0.022 & 0.043 & 0.125 \\
\hline
\end{tabular}

Table A3. Weights of economic subcriteria.

\begin{tabular}{cccc}
\hline \multirow{2}{*}{ Subcriteria } & $\mathrm{E}_{\mathbf{1}}$ & $\mathrm{E}_{\mathbf{2}}$ & $\mathrm{E}_{\mathbf{3}}$ \\
\cline { 2 - 4 } & TFN & TFN & TFN \\
\hline $\mathrm{E}_{1}$ & 0.080 & 0.150 & 0.446 \\
$\mathrm{E}_{2}$ & 0.158 & 0.493 & 1.337 \\
$\mathrm{E}_{3}$ & 0.116 & 0.356 & 1.040 \\
\hline
\end{tabular}


Table A4. Weights of alternatives relative to technical subcriteria.

\begin{tabular}{cccccccc}
\hline $\mathrm{T}_{\mathbf{1}}$ & \multicolumn{3}{c}{ Weights (TFN) } & $\mathrm{T}_{\mathbf{5}}$ & \multicolumn{3}{c}{ Weights (TFN) } \\
\hline $\mathrm{A}_{1}$ & 0.039 & 0.083 & 0.225 & $\mathrm{~A}_{1}$ & 0.229 & 0.430 & 0.758 \\
$\mathrm{~A}_{2}$ & 0.197 & 0.395 & 0.740 & $\mathrm{~A}_{2}$ & 0.095 & 0.232 & 0.515 \\
$\mathrm{~A}_{3}$ & 0.126 & 0.281 & 0.612 & $\mathrm{~A}_{3}$ & 0.026 & 0.039 & 0.085 \\
$\mathrm{~A}_{4}$ & 0.026 & 0.041 & 0.086 & $\mathrm{~A}_{4}$ & 0.039 & 0.097 & 0.228 \\
$\mathrm{~A}_{5}$ & 0.082 & 0.199 & 0.461 & $\mathrm{~A}_{5}$ & 0.115 & 0.201 & 0.394 \\
\hline $\mathrm{T}_{\mathbf{2}}$ & \multicolumn{3}{c}{ Weights (TFN) } & $\mathrm{T}_{\mathbf{6}}$ & \multicolumn{3}{c}{ Weights (TFN) } \\
\hline $\mathrm{A}_{1}$ & 0.205 & 0.405 & 0.741 & $\mathrm{~A}_{1}$ & 0.082 & 0.181 & 0.419 \\
$\mathrm{~A}_{2}$ & 0.027 & 0.041 & 0.090 & $\mathrm{~A}_{2}$ & 0.198 & 0.417 & 0.807 \\
$\mathrm{~A}_{3}$ & 0.085 & 0.181 & 0.375 & $\mathrm{~A}_{3}$ & 0.039 & 0.099 & 0.247 \\
$\mathrm{~A}_{4}$ & 0.041 & 0.106 & 0.290 & $\mathrm{~A}_{4}$ & 0.026 & 0.040 & 0.090 \\
$\mathrm{~A}_{5}$ & 0.131 & 0.266 & 0.547 & $\mathrm{~A}_{5}$ & 0.127 & 0.261 & 0.548 \\
\hline $\mathrm{T}_{\mathbf{3}}$ & \multicolumn{3}{c}{ Weights (TFN) } & $\mathrm{T}_{\mathbf{7}}$ & \multicolumn{3}{c}{ Weights (TFN) } \\
\hline $\mathrm{A}_{1}$ & 0.229 & 0.438 & 0.807 & $\mathrm{~A}_{1}$ & 0.029 & 0.048 & 0.118 \\
$\mathrm{~A}_{2}$ & 0.094 & 0.257 & 0.613 & $\mathrm{~A}_{2}$ & 0.134 & 0.254 & 0.513 \\
$\mathrm{~A}_{3}$ & 0.042 & 0.106 & 0.268 & $\mathrm{~A}_{3}$ & 0.057 & 0.173 & 0.444 \\
$\mathrm{~A}_{4}$ & 0.025 & 0.039 & 0.090 & $\mathrm{~A}_{4}$ & 0.209 & 0.441 & 0.855 \\
$\mathrm{~A}_{5}$ & 0.082 & 0.158 & 0.333 & $\mathrm{~A}_{5}$ & 0.041 & 0.083 & 0.193 \\
\hline $\mathrm{T}_{\mathbf{4}}$ & \multicolumn{3}{c}{ Weights (TFN) } & & $\mathrm{T}_{\mathbf{8}}$ & & Weights (TFN) \\
\hline $\mathrm{A}_{1}$ & 0.127 & 0.281 & 0.612 & $\mathrm{~A}_{1}$ & 0.039 & 0.097 & 0.228 \\
$\mathrm{~A}_{2}$ & 0.027 & 0.044 & 0.111 & $\mathrm{~A}_{2}$ & 0.229 & 0.430 & 0.758 \\
$\mathrm{~A}_{3}$ & 0.052 & 0.158 & 0.397 & $\mathrm{~A}_{3}$ & 0.026 & 0.039 & 0.085 \\
$\mathrm{~A}_{4}$ & 0.039 & 0.078 & 0.182 & $\mathrm{~A}_{4}$ & 0.127 & 0.256 & 0.515 \\
$\mathrm{~A}_{5}$ & 0.229 & 0.437 & 0.805 & $\mathrm{~A}_{5}$ & 0.082 & 0.177 & 0.394 \\
\hline & & & & & \\
\hline
\end{tabular}

Table A5. Weights of alternatives relative to production subcriteria.

\begin{tabular}{cccc}
\hline $\mathbf{P}_{\mathbf{1}}$ & \multicolumn{3}{c}{ Weights (TFN) } \\
\hline $\mathrm{A}_{1}$ & 0.132 & 0.260 & 0.513 \\
$\mathrm{~A}_{2}$ & 0.029 & 0.044 & 0.084 \\
$\mathrm{~A}_{3}$ & 0.086 & 0.179 & 0.372 \\
$\mathrm{~A}_{4}$ & 0.040 & 0.078 & 0.171 \\
$\mathrm{~A}_{5}$ & 0.239 & 0.438 & 0.755 \\
\hline $\mathbf{P}_{\mathbf{2}}$ & \multicolumn{3}{c}{ Weights (TFN) } \\
\hline $\mathrm{A}_{1}$ & 0.149 & 0.291 & 0.569 \\
$\mathrm{~A}_{2}$ & 0.078 & 0.163 & 0.334 \\
$\mathrm{~A}_{3}$ & 0.036 & 0.070 & 0.150 \\
$\mathrm{~A}_{4}$ & 0.026 & 0.038 & 0.072 \\
$\mathrm{~A}_{5}$ & 0.248 & 0.437 & 0.732 \\
\hline $\mathbf{P}_{\mathbf{3}}$ & \multicolumn{3}{c}{ Weights (TFN) } \\
\hline $\mathrm{A}_{1}$ & 0.029 & 0.042 & 0.079 \\
$\mathrm{~A}_{2}$ & 0.280 & 0.456 & 0.708 \\
$\mathrm{~A}_{3}$ & 0.091 & 0.160 & 0.292 \\
$\mathrm{~A}_{4}$ & 0.137 & 0.259 & 0.481 \\
$\mathrm{~A}_{5}$ & 0.044 & 0.081 & 0.156 \\
\hline
\end{tabular}


Table A5. Cont.

\begin{tabular}{cccc}
\hline $\mathbf{P}_{4}$ & \multicolumn{3}{c}{ Weights (TFN) } \\
\hline $\mathrm{A}_{1}$ & 0.028 & 0.046 & 0.127 \\
$\mathrm{~A}_{2}$ & 0.252 & 0.462 & 0.820 \\
$\mathrm{~A}_{3}$ & 0.080 & 0.172 & 0.374 \\
$\mathrm{~A}_{4}$ & 0.036 & 0.071 & 0.146 \\
$\mathrm{~A}_{5}$ & 0.092 & 0.247 & 0.577 \\
\hline $\mathbf{P}_{5}$ & \multicolumn{3}{c}{ Weights (TFN) } \\
\hline $\mathrm{A}_{1}$ & 0.025 & 0.039 & 0.090 \\
$\mathrm{~A}_{2}$ & 0.227 & 0.437 & 0.805 \\
$\mathrm{~A}_{3}$ & 0.040 & 0.104 & 0.264 \\
$\mathrm{~A}_{4}$ & 0.082 & 0.159 & 0.354 \\
$\mathrm{~A}_{5}$ & 0.096 & 0.260 & 0.612 \\
\hline $\mathbf{P}_{6}$ & \multicolumn{3}{c}{ Weights (TFN) } \\
\hline $\mathrm{A}_{1}$ & 0.028 & 0.040 & 0.075 \\
$\mathrm{~A}_{2}$ & 0.084 & 0.147 & 0.260 \\
$\mathrm{~A}_{3}$ & 0.265 & 0.452 & 0.728 \\
$\mathrm{~A}_{4}$ & 0.159 & 0.282 & 0.513 \\
$\mathrm{~A}_{5}$ & 0.042 & 0.077 & 0.149 \\
\hline $\mathbf{P}_{7}$ & \multicolumn{3}{c}{ Weights (TFN) } \\
\hline $\mathrm{A}_{1}$ & 0.024 & 0.035 & 0.072 \\
$\mathrm{~A}_{2}$ & 0.248 & 0.438 & 0.734 \\
$\mathrm{~A}_{3}$ & 0.079 & 0.163 & 0.335 \\
$\mathrm{~A}_{4}$ & 0.149 & 0.273 & 0.516 \\
$\mathrm{~A}_{5}$ & 0.037 & 0.090 & 0.204 \\
\hline
\end{tabular}

Table A6. Weights of alternatives relative to economic subcriteria.

\begin{tabular}{|c|c|c|c|c|c|c|c|c|c|c|c|}
\hline \multirow{2}{*}{$\frac{E_{1}}{A_{1}}$} & \multicolumn{3}{|c|}{ Weights (TFN) } & \multirow{2}{*}{$\frac{\mathrm{E}_{2}}{\mathrm{~A}_{1}}$} & \multicolumn{3}{|c|}{ Weights (TFN) } & \multirow{2}{*}{$\begin{array}{l}\mathrm{E}_{3} \\
\mathrm{~A}_{1}\end{array}$} & \multicolumn{3}{|c|}{ Weights (TFN) } \\
\hline & 0.039 & 0.078 & 0.188 & & 0.098 & 0.236 & 0.513 & & 0.263 & 0.441 & 0.713 \\
\hline $\mathrm{A}_{2}$ & 0.028 & 0.043 & 0.085 & $\mathrm{~A}_{2}$ & 0.039 & 0.075 & 0.145 & $\mathrm{~A}_{2}$ & 0.027 & 0.041 & 0.080 \\
\hline $\mathrm{A}_{3}$ & 0.095 & 0.232 & 0.515 & $\mathrm{~A}_{3}$ & 0.085 & 0.158 & 0.312 & $\mathrm{~A}_{3}$ & 0.083 & 0.172 & 0.352 \\
\hline $\mathrm{A}_{4}$ & 0.260 & 0.471 & 0.818 & $\mathrm{~A}_{4}$ & 0.031 & 0.052 & 0.127 & $\mathrm{~A}_{4}$ & 0.039 & 0.075 & 0.157 \\
\hline $\mathrm{A}_{5}$ & 0.082 & 0.175 & 0.374 & $\mathrm{~A}_{5}$ & 0.268 & 0.479 & 0.815 & $\mathrm{~A}_{5}$ & 0.129 & 0.270 & 0.542 \\
\hline
\end{tabular}

Table A7. Ultimate weights of subcriteria.

\begin{tabular}{ccccc}
\hline Subcriterion & Symbol & \multicolumn{3}{c}{ Weights (TFN) } \\
\hline $\mathrm{T}_{1}$ & $\mathrm{~W}_{1}$ & 0.018 & 0.073 & 0.288 \\
$\mathrm{~T}_{2}$ & $\mathrm{~W}_{2}$ & 0.015 & 0.063 & 0.245 \\
$\mathrm{~T}_{3}$ & $\mathrm{~W}_{3}$ & 0.002 & 0.008 & 0.034 \\
$\mathrm{~T}_{4}$ & $\mathrm{~W}_{4}$ & 0.013 & 0.054 & 0.223 \\
$\mathrm{~T}_{5}$ & $\mathrm{~W}_{5}$ & 0.004 & 0.021 & 0.095 \\
$\mathrm{~T}_{6}$ & $\mathrm{~W}_{6}$ & 0.015 & 0.056 & 0.204 \\
$\mathrm{~T}_{7}$ & $\mathrm{~W}_{7}$ & 0.007 & 0.021 & 0.079 \\
$\mathrm{~T}_{8}$ & $\mathrm{~W}_{8}$ & 0.008 & 0.035 & 0.153 \\
$\mathrm{P}_{1}$ & $\mathrm{~W}_{9}$ & 0.010 & 0.053 & 0.318 \\
$\mathrm{P}_{2}$ & $\mathrm{~W}_{10}$ & 0.025 & 0.143 & 0.689 \\
$\mathrm{P}_{3}$ & $\mathrm{~W}_{11}$ & 0.010 & 0.088 & 0.496 \\
$\mathrm{P}_{4}$ & $\mathrm{~W}_{12}$ & 0.006 & 0.038 & 0.214 \\
$\mathrm{P}_{5}$ & $\mathrm{~W}_{13}$ & 0.006 & 0.046 & 0.289 \\
$\mathrm{P}_{6}$ & $\mathrm{~W}_{14}$ & 0.013 & 0.086 & 0.467 \\
$\mathrm{P}_{7}$ & $\mathrm{~W}_{15}$ & 0.004 & 0.020 & 0.126 \\
$\mathrm{E}_{1}$ & $\mathrm{~W}_{16}$ & 0.009 & 0.028 & 0.191 \\
$\mathrm{E}_{2}$ & $\mathrm{~W}_{17}$ & 0.017 & 0.094 & 0.574 \\
$\mathrm{E}_{3}$ & $\mathrm{~W}_{18}$ & 0.013 & 0.068 & 0.446 \\
\hline
\end{tabular}


Table A8. Elements of the performance matrix.

\begin{tabular}{|c|c|c|c|c|c|c|c|c|c|}
\hline Weight & Alt. & \multicolumn{3}{|c|}{ Fuzzy Number } & Weight & Alt. & \multicolumn{3}{|c|}{ Fuzzy Number } \\
\hline \multirow{5}{*}{$\mathrm{W}_{1}$} & $\mathrm{~A}_{1}$ & 0.000728 & 0.006069 & 0.065084 & \multirow{5}{*}{$\mathrm{W}_{10}$} & $\mathrm{~A}_{1}$ & 0.003817 & 0.041651 & 0.392601 \\
\hline & $\mathrm{A}_{2}$ & 0.003641 & 0.028898 & 0.213848 & & $\mathrm{~A}_{2}$ & 0.002021 & 0.023312 & 0.230513 \\
\hline & $\mathrm{A}_{3}$ & 0.002333 & 0.020533 & 0.176657 & & $\mathrm{~A}_{3}$ & 0.000928 & 0.010042 & 0.103385 \\
\hline & $\mathrm{A}_{4}$ & 0.000482 & 0.003005 & 0.024825 & & $\mathrm{~A}_{4}$ & 0.000666 & 0.005505 & 0.049916 \\
\hline & $\mathrm{A}_{5}$ & 0.001512 & 0.014571 & 0.133237 & & $\mathrm{~A}_{5}$ & 0.006362 & 0.062491 & 0.504773 \\
\hline Weight & Alt. & \multicolumn{3}{|c|}{ Fuzzy Number } & Weight & Alt. & \multicolumn{3}{|c|}{ Fuzzy Number } \\
\hline \multirow{5}{*}{$\mathrm{W}_{2}$} & $\mathrm{~A}_{1}$ & 0.003029 & 0.025452 & 0.181489 & \multirow{5}{*}{$\mathrm{W}_{11}$} & $\mathrm{~A}_{1}$ & 0.000311 & 0.003785 & 0.039362 \\
\hline & $\mathrm{A}_{2}$ & 0.000398 & 0.002599 & 0.022094 & & $\mathrm{~A}_{2}$ & 0.002971 & 0.040417 & 0.351445 \\
\hline & $\mathrm{A}_{3}$ & 0.001258 & 0.011386 & 0.092007 & & $\mathrm{~A}_{3}$ & 0.000966 & 0.014238 & 0.145217 \\
\hline & $\mathrm{A}_{4}$ & 0.000606 & 0.006684 & 0.071018 & & $\mathrm{~A}_{4}$ & 0.001456 & 0.022964 & 0.238982 \\
\hline & $\mathrm{A}_{5}$ & 0.001941 & 0.016745 & 0.134144 & & $\mathrm{~A}_{5}$ & 0.000467 & 0.007194 & 0.07774 \\
\hline Weight & Alt. & \multicolumn{3}{|c|}{ Fuzzy Number } & Weight & Alt. & \multicolumn{3}{|c|}{ Fuzzy Number } \\
\hline \multirow{5}{*}{$\mathrm{W}_{3}$} & $\mathrm{~A}_{1}$ & 0.00048 & 0.003662 & 0.027639 & \multirow{5}{*}{$\mathrm{W}_{12}$} & $\mathrm{~A}_{1}$ & 0.000178 & 0.001774 & 0.027396 \\
\hline & $\mathrm{A}_{2}$ & 0.000198 & 0.00215 & 0.021005 & & $\mathrm{~A}_{2}$ & 0.001614 & 0.017546 & 176119 \\
\hline & $\mathrm{A}_{3}$ & $8.74 \mathrm{E}-05$ & 0.000886 & 0.009209 & & $\mathrm{~A}_{3}$ & 0.000513 & 0.006545 & 0.080428 \\
\hline & $\mathrm{A}_{4}$ & $5.28 \mathrm{E}-05$ & 0.00033 & 0.003096 & & $\mathrm{~A}_{4}$ & 0.000233 & 0.002716 & 0.03131 \\
\hline & $\mathrm{A}_{5}$ & 0.000173 & 0.001322 & 0.01142 & & $\mathrm{~A}_{5}$ & 0.000589 & 0.009406 & 0.123936 \\
\hline Weight & Alt. & \multicolumn{3}{|c|}{ Fuzzy Number } & Weight & Alt. & \multicolumn{3}{|c|}{ Fuzzy Number } \\
\hline \multirow{5}{*}{$\mathrm{W}_{4}$} & $\mathrm{~A}_{1}$ & 0.001751 & 0.015312 & 0.136508 & \multirow{5}{*}{$\mathrm{W}_{13}$} & $\mathrm{~A}_{1}$ & 0.000168 & 0.001832 & 0.026059 \\
\hline & $\mathrm{A}_{2}$ & 0.000374 & 0.002427 & 0.024931 & & $\mathrm{~A}_{2}$ & 0.001527 & 0.020354 & 0.232674 \\
\hline & $\mathrm{A}_{3}$ & 0.000715 & 0.008597 & 0.088586 & & $\mathrm{~A}_{3}$ & 0.000272 & 0.004842 & 0.076317 \\
\hline & $\mathrm{A}_{4}$ & 0.000534 & 0.004287 & 0.040665 & & $\mathrm{~A}_{4}$ & 0.00055 & 0.007424 & 0.102377 \\
\hline & $\mathrm{A}_{5}$ & 0.003152 & 0.023818 & 0.179616 & & $\mathrm{~A}_{5}$ & 0.000644 & 0.012116 & 0.176832 \\
\hline Weight & Alt. & \multicolumn{3}{|c|}{ Fuzzy Number } & Weight & Alt. & & zzy Numb & \\
\hline & $\mathrm{A}_{1}$ & 0.001019 & 0.009255 & 0.072218 & & $\mathrm{~A}_{1}$ & 0.000358 & 0.003486 & 0.035279 \\
\hline & $\mathrm{A}_{2}$ & 0.000421 & 0.004993 & 0.049108 & & $\mathrm{~A}_{2}$ & 0.001086 & 0.012693 & 0.121712 \\
\hline $\mathrm{W}_{5}$ & $\mathrm{~A}_{3}$ & 0.000116 & 0.000855 & 0.008088 & $\mathrm{~W}_{14}$ & $\mathrm{~A}_{3}$ & 0.00342 & 0.038926 & 0.34019 \\
\hline & $\mathrm{A}_{4}$ & 0.000172 & 0.002092 & 0.021752 & & $\mathrm{~A}_{4}$ & 0.002052 & 0.024253 & 0.239393 \\
\hline & $\mathrm{A}_{5}$ & 0.000511 & 0.004332 & 0.037553 & & $\mathrm{~A}_{5}$ & 0.000537 & 0.006628 & 0.069676 \\
\hline Weight & Alt. & & zzy Numb & & Weight & Alt. & & zzy Numb & \\
\hline & $\mathrm{A}_{1}$ & 0.001248 & 0.010096 & 0.085902 & & $\mathrm{~A}_{1}$ & 0.000107 & 0.000732 & 0.009131 \\
\hline & $\mathrm{A}_{2}$ & 0.003004 & 0.023315 & 0.165196 & & $\mathrm{~A}_{2}$ & 0.001098 & 0.009068 & 0.092337 \\
\hline $\mathrm{W}_{6}$ & $\mathrm{~A}_{3}$ & 0.000587 & 0.005572 & 0.050616 & $\mathrm{~W}_{15}$ & $\mathrm{~A}_{3}$ & 0.000349 & 0.003383 & 0.042167 \\
\hline & $\mathrm{A}_{4}$ & 0.000395 & 0.002262 & 0.018502 & & $\mathrm{~A}_{4}$ & 0.000659 & 0.00565 & 0.064978 \\
\hline & $\mathrm{A}_{5}$ & 0.001925 & 0.014572 & 0.112333 & & $\mathrm{~A}_{5}$ & 0.000164 & 0.001871 & 0.025752 \\
\hline Weight & Alt. & & 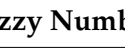 & & Weight & Alt. & & 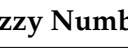 & \\
\hline & $\mathrm{A}_{1}$ & 0.000202 & 0.00105 & 0.009398 & & $\mathrm{~A}_{1}$ & 0.000346 & 0.002245 & 0.035966 \\
\hline & $\mathrm{A}_{2}$ & 0.000913 & 0.005516 & 0.040626 & & $\mathrm{~A}_{2}$ & 0.000251 & 0.001238 & 0.016243 \\
\hline $\mathrm{W}_{7}$ & $\mathrm{~A}_{3}$ & 0.000387 & 0.003756 & 0.03521 & $\mathrm{~W}_{16}$ & $\mathrm{~A}_{3}$ & 0.000846 & 0.006649 & 0.098616 \\
\hline & $\mathrm{A}_{4}$ & 0.001425 & 0.009593 & 0.067711 & & $\mathrm{~A}_{4}$ & 0.002319 & 0.013498 & 0.156626 \\
\hline & $\mathrm{A}_{5}$ & 0.000278 & 0.001813 & 0.01533 & & $\mathrm{~A}_{5}$ & 0.000737 & 0.005035 & 0.071526 \\
\hline Weight & Alt. & & zzy Numl & & Weight & Alt. & & zzy Numb & \\
\hline & $\mathrm{A}_{1}$ & 0.000329 & 0.003452 & 0.03495 & & $\mathrm{~A}_{1}$ & 0.001711 & 0.022177 & 0.294687 \\
\hline & $\mathrm{A}_{2}$ & 0.001945 & 0.015274 & 0.116035 & & $\mathrm{~A}_{2}$ & 0.000693 & 0.007066 & 0.083206 \\
\hline $\mathrm{W}_{8}$ & $\mathrm{~A}_{3}$ & 0.000222 & 0.001411 & 0.012996 & $\mathrm{~W}_{17}$ & $\mathrm{~A}_{3}$ & 0.00149 & 0.014837 & 0.179066 \\
\hline & $\mathrm{A}_{4}$ & 0.00108 & 0.009092 & 0.078904 & & $\mathrm{~A}_{4}$ & 0.000552 & 0.004886 & 0.072805 \\
\hline & $\mathrm{A}_{5}$ & 0.0007 & 0.006299 & 0.060338 & & $\mathrm{~A}_{5}$ & 0.004691 & 0.045019 & 0.468033 \\
\hline Weight & Alt. & & zzy Numl & & Weight & Alt. & & zzy Numb & \\
\hline & $\mathrm{A}_{1}$ & 0.001375 & 0.013901 & 0.163554 & & $\mathrm{~A}_{1}$ & 0.003369 & 0.029912 & 0.318404 \\
\hline & $\mathrm{A}_{2}$ & 0.000304 & 0.002346 & 0.026938 & & $\mathrm{~A}_{2}$ & 0.000353 & 0.002801 & 0.035661 \\
\hline $\mathrm{W}_{9}$ & $\mathrm{~A}_{3}$ & 0.000891 & 0.009541 & 0.118625 & $\mathrm{~W}_{18}$ & $\mathrm{~A}_{3}$ & 0.00107 & 0.011666 & 0.157037 \\
\hline & $\mathrm{A}_{4}$ & 0.000419 & 0.004204 & 0.054454 & & $\mathrm{~A}_{4}$ & 0.000503 & 0.005093 & 0.070431 \\
\hline & $\mathrm{A}_{5}$ & 0.002475 & 0.023353 & 0.240521 & & $\mathrm{~A}_{5}$ & 0.001651 & 0.018355 & 0.241987 \\
\hline
\end{tabular}




\section{References}

1. Saaty, T.L. The Analytic Hierarchy Process: Planning, Priority Setting, Resource Allocation; McGraw-Hill: New York, NY, USA, 1980.

2. Badi, I.; Abdulshahed, A.; Shetwan, A.; Eltayeb, W. Evaluation of solid waste treatment methods in Libya by using the analytic hierarchy process. Decis. Mak. Appl. Manag. Eng. 2019, 2, 19-35. [CrossRef]

3. Kovačević, N.; Stojiljković, A.; Kovač, M. Application of the matrix approach in risk assessment. Oper. Res. Eng. Sci. Theory Appl. 2019, 2, 55-64. [CrossRef]

4. Zhang, H.; Sun, Q. An Integrated MCDM Approach to Train Derailment Risk Response Strategy Selection. Symmetry 2020, 12, 47. [CrossRef]

5. Guo, Q.; Guo, G.; Li, Y.; Lei, W.; Zhao, X. Stability Evaluation of an Expressway Construction Site above an Abandoned Coal Mine Based on the Overlay and Index Method. Sustainability 2019, 11, 5163. [CrossRef]

6. Pipatprapa, A.; Huang, H.-H.; Huang, C.-H. A Novel Environmental Performance Evaluation of Thailand's Food Industry Using Structural Equation Modeling and Fuzzy Analytic Hierarchy Techniques. Sustainability 2016, 8, 246. [CrossRef]

7. Lee, A.H.I.; Kang, H.-Y.; Lin, C.-Y.; Shen, K.-C. An Integrated Decision-Making Model for the Location of a PV Solar Plant. Sustainability 2015, 7, 13522-13541. [CrossRef]

8. Chatterjee, P.; Stević, Ž. A two-phase fuzzy AHP-fuzzy TOPSIS model for supplier evaluation in manufacturing environment. Oper. Res. Eng. Sci. Theory Appl. 2019, 2, 72-90. [CrossRef]

9. Bozanić, D.; Tešić, D.; Milićević, J. A hybrid fuzzy AHP-MABAC model: Application in the Serbian Army-The selection of the location for deep wading as a technique of crossing the river by tanks. Decis. Mak. Appl. Manag. Eng. 2018, 1, 143-164. [CrossRef]

10. Stanković, M.; Gladović, P.; Popović, V. Determining the importance of the criteria of traffic accessibility using fuzzy AHP and rough AHP method. Decis. Mak. Appl. Manag. Eng. 2019, 2, 86-104. [CrossRef]

11. Mallick, J.; Khan, R.A.; Ahmed, M.; Alqadhi, S.D.; Alsubih, M.; Falqi, I.; Hasan, M.A. Modeling Groundwater Potential Zone in a Semi-Arid Region of Aseer Using Fuzzy-AHP and Geoinformation Techniques. Water 2019, 11, 2656. [CrossRef]

12. Özfırat, M.K. A fuzzy method for selecting underground coal mining method considering mechanization criteria. J. Min. Sci. 2012, 48, 533-544. [CrossRef]

13. Chander, B.B.; Gorai, A.K.; Jayantu, S. Design of Decision-Making Techniques Using Improved AHP and VIKOR for Selection of Underground Mining Method. Recent Find. Intell. Comput. Tech. 2018, 495-504. [CrossRef]

14. Balusa, B.C.; Gorai, A.K. A Comparative Study of Various Multi-criteria Decision-Making Models in Underground Mining Method Selection. J. Inst. Eng. (India) Ser. D 2018, 100, 105. [CrossRef]

15. Balusa, B.C.; Gorai, A.K. Sensitivity analysis of fuzzy-analytic hierarchical process (FAHP) decision making model in selection of underground metal mining method. J. Sustain. Min. 2019, 18, 8-17. [CrossRef]

16. Bogdanovic, D.; Nikolic, D.; Ilic, I. Mining method selection by integrated AHP and PROMETHEE method. Ann. Braz. Acad. Sci. 2012, 84, 219-233. [CrossRef]

17. Aplay, S.; Yavuz, M. A Decision Support System for Underground Mining Method Selection. In Proceedings of the 20th International Conference on Industrial, Engineering and Other Applications of Applied Intelligent Systems, Kyoto, Japan, 26-29 June 2007; pp. 334-343.

18. Yazdani-Chamzini, A.; Yakchali, S.H.; Zavadskas, E.K. Using a integrated MCDM model for mining method selection in presence of uncertainty. Econ. Res. 2012, 869-904. [CrossRef]

19. Asadi Ooriad, F.; Yari, M.; Bagherpour, R.; Khoshouei, M. The development of a novel Model for Mining Method Selection in a Fuzzy Environment; Case study: Tazareh Coal Mine, Semnan Province, Iran. Min. Geol. Pet. Eng. Bull. 2018, 45-53. [CrossRef]

20. Javanshirgiv, M.; Safari, M. The selection of an underground mining method using the Fuzzy TOPSIS method: A case study in the Kamar Mahdi II fluorine mine, Iran. Min. Sci. 2017, 24, 161-181. [CrossRef]

21. Ataei, M.; Sereshki, F.; Jamshidi, M.; Jalali, S.M.E. Suitable mining method for Golbini No. 8 deposit in Jajarm (Iran) using TOPSIS method. Min. Technol. 2008, 117, 1-5. [CrossRef]

22. Naghadehi, M.Z.; Mikaeil, R.; Ataei, M. The application of fuzzy analytic hierarchy process (FAHP) approach to selection of optimum underground mining method for Jajarm Bauxite Mine, Iran. Expert Syst. Appl. 2009, 8218-8226. [CrossRef] 
23. Bajić, D.; Polomčić, D.; Ratković, J. Multi-criteria decision analysis for the purposes of groundwater control system design. Water Resour. Manag. 2017, 31, 4759-4784. [CrossRef]

24. Polomčić, D.; Gligorić, Z.; Bajić, D.; Gligorić, M.; Negovanović, M. Multi-criteria fuzzy-stochastic diffusion model of groundwater control system selection. Symmetry 2019, 11, 705. [CrossRef]

25. Zadeh, L.A. Fuzzy sets. Inf. Control. 1965, 8, 338-353. [CrossRef]

26. Chang, D.Y. Applications of the extent analysis method on fuzzy AHP. Eur. J. Oper. Res. 1996, 95, 649-655. [CrossRef]

27. Saaty, T.L. How to make a decision: The analytic hierarchy process. Eur. J. Oper. Res. 1990, 48, 9-26. [CrossRef]

28. Zhu, K.; Jing, Y.; Chang, D. A discussion on extent analysis method and applications of fuzzy AHP. Eur. J. Oper. Res. 1999, 116, 450-456. [CrossRef]

29. Lamata, M.T. Ranking of alternatives with ordered weighted averaging operators. Int. J. Intell. Syst. 2004, 19, 473-482. [CrossRef]

30. Deng, H. Multicriteria analysis with fuzzy pair-wise comparison. Int. J. Approx. Reason. 1999, 21, $215-231$. [CrossRef]

31. Zadeh, L.A. The concept of a liguistic variable and its application to approximate reasoning. Inf. Sci. 1975, 8, 199-249. [CrossRef]

32. Van Broekhoven, E. A comparison of three methods for computing the center of gravity defuzzification. Proc. Int. Conf. Fuzzy Syst. 2004, 3, 1537-1542.

33. Liou, T.S.; Wang, M.J.J. Ranking fuzzy numbers with integral value. Fuzzy Sets Syst. 1992, 50, $247-256$. [CrossRef]

34. Kwang, H.C.; Lee, H.J. A method for ranking fuzzy numbers and its application to decision making. IEEE Trans. Fuzzy Syst. 1999, 7, 677-685. [CrossRef]

35. Ataei, M.; Jamshidi, M.; Sereshki, F.; Jalali, S.M.E. Mining method selection by AHP approach. J. S. Afr. Inst. Min. Metall. 2008, 108, 741-749.

(C) 2020 by the authors. Licensee MDPI, Basel, Switzerland. This article is an open access article distributed under the terms and conditions of the Creative Commons Attribution (CC BY) license (http://creativecommons.org/licenses/by/4.0/). 